\title{
ARTICLE
}

\section{1,5-Naphthyl-linked bis(imino)pyridines as binucleating scaffolds for dicobalt ethylene oligo-/polymerization catalysts: exploring temperature and steric effects}

Received 00th January 20xx, Accepted 00th January 20xx DOI: $10.1039 / \times 0 \times x 00000 x$

\section{Introduction}

The bis(imino)pyridine class of transition metal catalyst for ethylene polymerization and especially those involving iron and cobalt, remains a subject of enduring research activity ever since their inception over twenty years ago. ${ }^{1}$ This can, in some measure, be accredited to the straightforward synthesis of the precatalyst, the high activity of the active species and moreover to its capacity to mediate the formation a range of highly prized materials including $\alpha$-olefins, linear waxes and high molecular weight polyethylenes. Largely, these research efforts have been concerned with modifications to the bis(imino)pyridine supporting ligand and indeed progress in this field has been thoroughly documented. ${ }^{2}$

Elsewhere, the design of pyridylimine-based ligand frameworks that can accommodate more than one active iron

a. Key Laboratory of Engineering Plastics and Beijing National Laboratory for Molecular Sciences, Institute of Chemistry, Chinese Academy of Sciences, Beijing 100190, China.E-mail: whsun@iccas.ac.cn.

b. School of Materials Science and Engineering, Beijing Institute of Fashion Technology, Beijing 100029, China.E-mail: zhangwj@bift.edu.cn.

c. Department of Chemistry, University of Leicester, University Road, Leicester LE1 7RH, UK. E-mail: gas8@le.ac.uk.

d. State Key Laboratory for Oxo Synthesis and Selective Oxidation, Lanzhou Institute of Chemical Physics, Chinese Academy of Sciences, Lanzhou 730000, China.

+ Electronic Supplementary Information (ESI) available. CCDC 1902895 for L2, 1902896 for Co3, 1902897 for Co5. For ESI and crystallographic data in CIF or other electronic format see DOI: 10.1039/x0xx00000x or cobalt center has emerged as a promising research direction due to potential cooperative effects that can result on account of the close proximity of the active sites. ${ }^{3}$ Indeed a wide variety of such compartmental ligands have been reported that incorporate two binding domains including $N, N / N, N, N$ (bi/tridentate) $)^{4-6}$ as well as $N, N, N / N, N, N$ (bis(tridentate)). ${ }^{7-11}$ In terms of polymerization applications, the bis(tridentate) examples derived from linked bis(imino)pyridines have proved among the most effective with many of the resulting multinuclear complexes reported to display not only high activities but also performance characteristics that can be dissimilar to their mononuclear comparators. ${ }^{11}$ Nevertheless, the steric and electronic properties of the binucleating ligand frame retains a key role in influencing the catalytic performance of all classes of binuclear catalyst, while the nature and location of the linking unit presents an additional factor that can affect among other things, metal...metal separation, flexibility and electron transfer pathways. ${ }^{3 a, 12}$

With particular regard to dinuclear cobalt catalysts, a wide variety of precatalysts have been reported for ethylene polymerization. For example, Takeuchi's group reported the 'double-decker' binuclear cobalt species A (Chart 1), which though displaying only moderate activity, generated polyethylene with much higher molecular weight than observed with its mononuclear analogues. ${ }^{9}$ By contrast, the bi/tridentate examples $\mathbf{B}^{4}$ and $\mathbf{C}^{5 a}$ (Chart 1 ) both showed 
improved activity when compared to their monocobalt counterparts and notably in the case of $\mathbf{C}$, at higher operating temperature; oligomers (B) or mixtures of oligomers and polymer (C) were in these cases obtained. On the other hand,

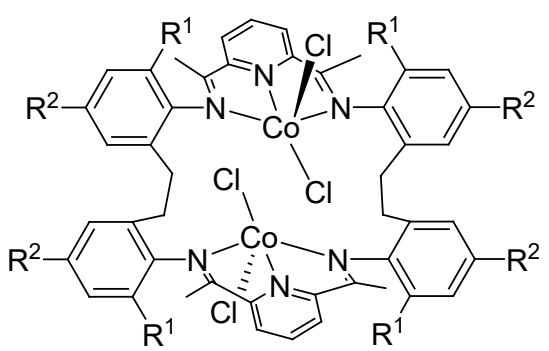

A

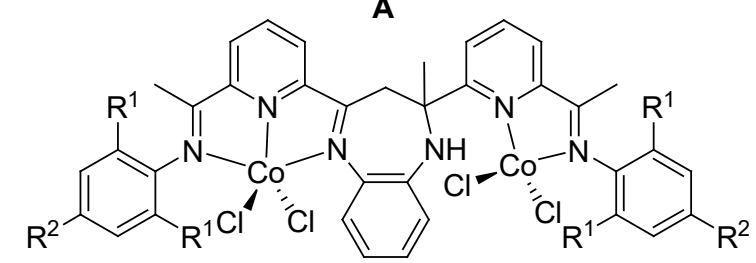

C

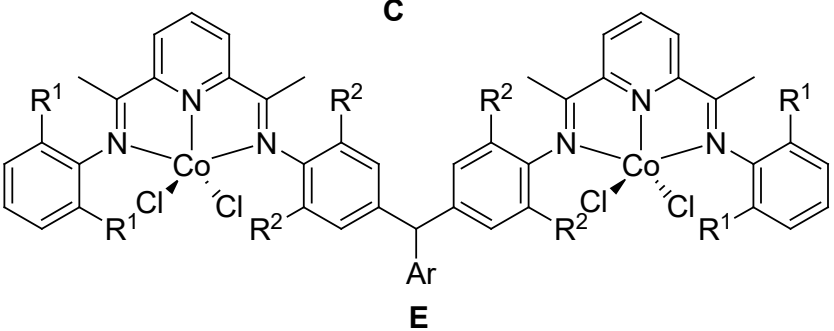

the bis(tridentate) systems $\mathbf{D}^{10 b}$ and $\mathbf{E}^{11 a}$ were found to have a propensity towards forming polyethylene waxes with high levels of vinyl chain ends.

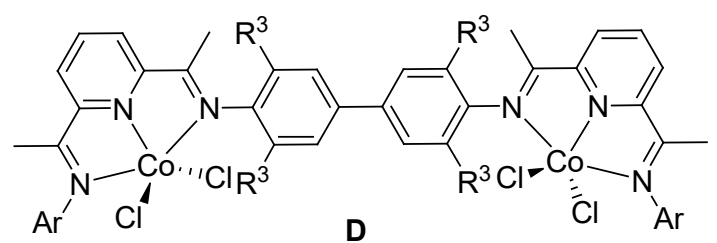

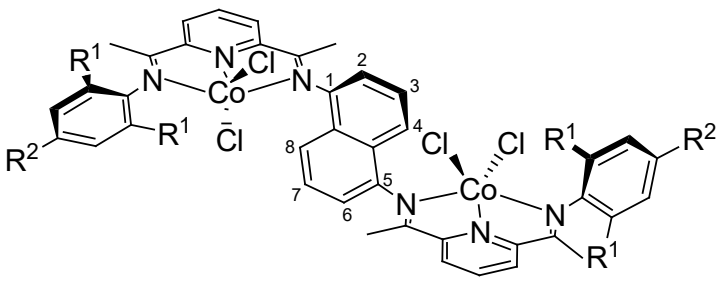

F (this work)

Chart 1 Some examples of previously reported binucleating scaffolds for dinuclear cobalt(II) chloride precatalysts, A-E, along with target F.

In this work we are concerned with employing a 1,5substituted naphthyl group as a means to link two bis(imino)pyridine-cobalt(II) chloride precatalysts (F, Chart 1 ). Given the absence of any significant steric properties at the 2and 6-positions of the naphthyl linker in $\mathbf{F}$, we considered that the two $(N, N, N) \mathrm{CoCl}_{2}$ units would display some flexibility in their relative configuration which in turn could influence the performance of the resulting catalyst. To this end, we first report the synthesis of six examples of $\mathbf{F}$ that differ in the steric $\left(\mathrm{R}^{1}=\mathrm{Me}, \mathrm{Et},{ }^{\mathrm{P} P}\right.$ and $\left.\mathrm{CHPh}_{2}\right)$ and electronic $\left(\mathrm{R}^{2}=\mathrm{H}\right.$ or $\left.\mathrm{Me}\right)$ profile of the exterior $\mathrm{N}$-aryl groups (F, Chart 1). Secondly, an in-depth catalytic evaluation of $\mathbf{F}$ as precatalysts for ethylene polymerization is undertaken to explore any correlations between not only structure and activity but also structure and polymer properties; the effects of temperature, pressure and co-catalyst represent additional parameters to be probed. Full synthetic and characterization details for the ligands and complexes are additionally presented.

\section{Results and discussion}

Synthesis of the ligands and complexes
The 1,5-naphthyl-bridged bis(imino)pyridines, 1,5-\{2-(CMe=N)$\left.6-\left(\mathrm{CMe}=\mathrm{N}\left(2,6-\mathrm{R}^{1}{ }_{2}-4-\mathrm{R}^{2}-\mathrm{C}_{6} \mathrm{H}_{2}\right)\right) \mathrm{C}_{5} \mathrm{H}_{3} \mathrm{~N}\right\}_{2}\left(\mathrm{C}_{10} \mathrm{H}_{6}\right)\left(\mathrm{R}^{1}=\mathrm{Me}, \mathrm{R}^{2}=\mathrm{H}\right.$ L1; $R^{1}=E t, R^{2}=$ H L2; $R^{1}={ }^{i} \operatorname{Pr}, R^{2}=H$ L3; $R^{1}=$ Me, $R^{2}=$ Me L4; $R^{1}$ $=\mathrm{Et}, \mathrm{R}^{2}=\mathrm{Me} \mathbf{L} \mathbf{5} ; \mathrm{R}^{1}=\mathrm{CHPh}_{2}, \mathrm{R}^{2}=\mathrm{Me} \mathbf{L 6}$ ), have been prepared in moderate yield by the acid-catalyzed condensation reaction of 1,5-diaminonaphthalene with just over two equivalents of the appropriate 2-acetyl-6-aryliminopyridine, 2-(CMeO)-6$\left\{C M e=N\left(2,6-R^{1}{ }_{2}-4-R^{2}-C_{6} H_{2}\right)\right\} C_{5} H_{3} N\left(R^{1}=M e, R^{2}=H ; R^{1}=E t, R^{2}=\right.$ $\mathrm{H} ; \mathrm{R}^{1}={ }^{i} \mathrm{Pr}, \mathrm{R}^{2}=\mathrm{H} ; \mathrm{R}^{1}=\mathrm{R}^{2}=\mathrm{Me} ; \mathrm{R}^{1}=\mathrm{Et}, \mathrm{R}^{2}=\mathrm{Me} ; \mathrm{R}^{1}=\mathrm{CHPh}_{2}, \mathrm{R}^{2}$ $=\mathrm{Me}$ ) (Scheme 1). These imine-ketones are not commercially available and have been prepared using literature procedures. ${ }^{13}$ All new organic compounds have been characterized by ${ }^{1} \mathrm{H} /{ }^{13} \mathrm{C} N M R$ and $\mathrm{FT}$-IR spectroscopy as well as by elemental analysis; a crystal of $\mathbf{L} \mathbf{2}$ has additionally been used for a single crystal X-ray diffraction study.

Interaction of L1 - L6 with two equivalents of anhydrous cobalt dichloride in methanol at room temperature afforded, $\left[1,5-\left\{2-(\mathrm{CMe}=\mathrm{N})-6-\left(\mathrm{CMe}=\mathrm{N}\left(2,6-\mathrm{R}^{1}{ }_{2}-4-\mathrm{R}^{2}-\right.\right.\right.\right.$

$\left.\left.\left.\mathrm{C}_{6} \mathrm{H}_{2}\right)\right) \mathrm{C}_{5} \mathrm{H}_{3} \mathrm{~N}_{2}\left(\mathrm{C}_{10} \mathrm{H}_{6}\right)\right] \mathrm{Co}_{2} \mathrm{Cl}_{4}\left(\mathrm{R}^{1}=\mathrm{Me}, \mathrm{R}^{2}=\mathrm{H}\right.$ Co1; $\mathrm{R}^{1}=\mathrm{Et}, \mathrm{R}^{2}=\mathrm{H}$ Co2; $R^{1}={ }^{i} \mathrm{Pr}, \mathrm{R}^{2}=\mathrm{H}$ Co3; $\mathrm{R}^{1}=\mathrm{Me}, \mathrm{R}^{2}=\mathrm{Me} \mathrm{Co} 4 ; \mathrm{R}^{1}=\mathrm{Et}, \mathrm{R}^{2}=\mathrm{Me}$ Co5; $\mathrm{R}^{1}=\mathrm{CHPh}_{2}, \mathrm{R}^{2}=\mathrm{Me}$ Co6), in good to high yields (Scheme 1). All new complexes have been characterized by FT-IR spectroscopy and elemental analysis. In addition, Co3 and Co5 have been the subject of single crystal X-ray diffraction studies. 


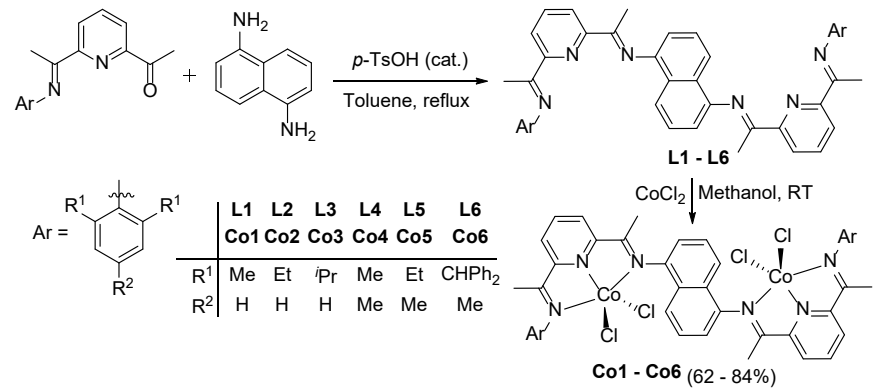

Scheme 1 Synthetic route to Co1 - Co6 via L1 - L6

Single crystals of $\mathrm{Co} 3$ and $\mathrm{Co5}$ suitable for the X-ray determinations were grown by slow diffusion of diethyl ether into dimethylformamide solutions of the corresponding complex. Perspective views of each cobalt structure are shown in Figures 2 and 3 while the structure of the free ligand $\mathbf{L} \mathbf{2}$ is also presented in Figure 1; selected bond lengths and angles for all three species are tabulated in Table 1 . In each case, the full molecules have been symmetry generated through an inversion center located at the centroid of the naphthyl linker. The structures of the two complexes are similar and consist of a bis(tridentate) compartmental ligand that makes use of its two $\mathrm{N}, \mathrm{N}, \mathrm{N}$-pockets to house the $\mathrm{CoCl}_{2}$ moieties. Moreover the resulting $(\mathrm{N}, \mathrm{N}, \mathrm{N}) \mathrm{CoCl}_{2}$ units adopt an anti-configuration around the 1,5-naphthyl linker with the result that the Co $\cdots$ Co separations are $9.523 \AA$ for $\mathrm{Co3}$ and $9.283 \AA$ for Co5. By contrast in L2, the neighboring nitrogen atoms belonging to each $\mathrm{N}, \mathrm{N}, \mathrm{N}$-unit are configured in a transoid arrangement in a manner similar to that seen in a range of oligopyridylimines. ${ }^{14}$ All the cobalt atoms in $\mathrm{Co} 3$ and $\mathrm{Co5}$ are five-coordinate with each geometry best described as distorted trigonal bipyramidal with the pyridine nitrogen atom and two chlorides defining the equatorial plane. Akin to that seen with a number of previously reported mononuclear bis(imino)pyridinecobalt(II) chloride complexes, the exterior Co- $\mathrm{N}_{\text {imine }}$ distances are around $0.190 \AA$ longer than the central Co- $\mathrm{N}_{\text {pyridine }}$ distances, ${ }^{15}$ while the $\mathrm{N}$-aryl groups are inclined almost perpendicularly to the neighboring external and internal imine vectors (dihedral angles: $82.30_{\mathrm{ext}^{\circ}}, 90.80_{\mathrm{int}}{ }^{\circ}$ (Co3), $88.61_{\mathrm{ext}}{ }^{\circ}$ and $90.80_{\text {int }}^{\circ}(\mathrm{Co5})$ ). As expected the two fused aryl units belonging to the central 1,5-naphthyl linker in all three structures are virtually coplanar. There are no intermolecular contacts of note.

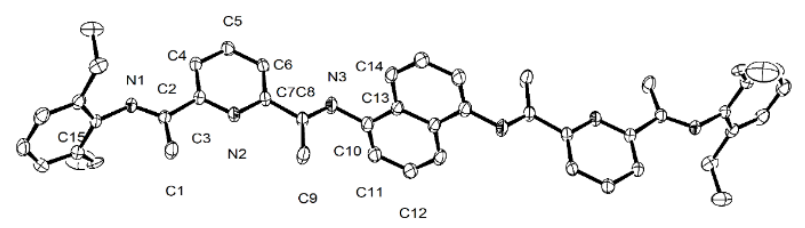

Figure 1 ORTEP representation of $\mathbf{L} 2$. The thermal ellipsoids are shown at $30 \%$ probability level and the hydrogen atoms are omitted for clarity.

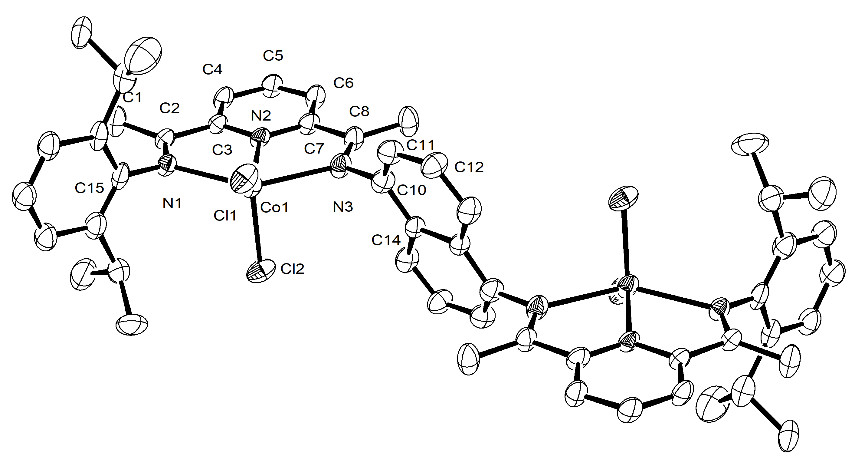

Figure 2 ORTEP representation of Co3. The thermal ellipsoids are shown at $30 \%$ probability level and the hydrogen atoms are omitted for clarity.

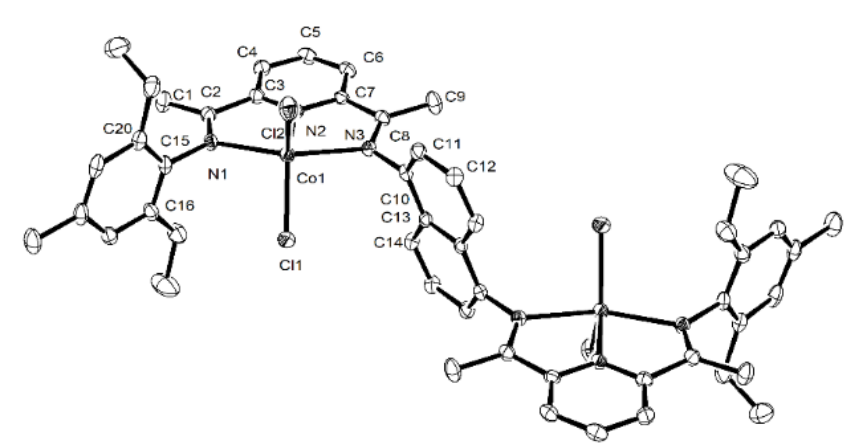

Figure 3 ORTEP representation of Co5. Thermal ellipsoids are shown at the $30 \%$ probability level and hydrogen atoms omitted for clarity.

Table 1 Selected bond lengths $(\AA \AA)$ and angles $\left({ }^{\circ}\right)$ for L2, Co3 and Co5

\begin{tabular}{|c|c|c|c|}
\hline & $\mathbf{L 2}$ & Co3 & Co5 \\
\hline \multicolumn{4}{|l|}{ Bond lengths $(\AA ̊)$} \\
\hline $\operatorname{Co}(1)-N(1)$ & & $2.239(4)$ & $2.204(4)$ \\
\hline $\mathrm{Co}(1)-\mathrm{N}(2)$ & & $2.037(4)$ & $2.030(4)$ \\
\hline Co(1)-N(3) & & $2.235(4)$ & $2.203(4)$ \\
\hline$N(1)-C(2)$ & $1.279(3)$ & $1.281(6)$ & $1.284(6)$ \\
\hline$N(1)-C(15)$ & $1.435(3)$ & $1.33(5)$ & $1.459(5)$ \\
\hline$N(2)-C(3)$ & $1.347(3)$ & $1.335(6)$ & $1.346(6)$ \\
\hline$N(2)-C(7)$ & $1.348(3)$ & $1.343(6)$ & $1.349(5)$ \\
\hline$N(3)-C(10)$ & $1.429(4)$ & $1.464(7)$ & $1.437(6)$ \\
\hline$N(3)-C(8)$ & $1.277(4)$ & $1.267(6)$ & $1.281(5)$ \\
\hline $\operatorname{Co}(1) \cdots \operatorname{Co}(1 \mathrm{~A})$ & & 9.523 & 9.283 \\
\hline \multicolumn{4}{|c|}{ Bond angles $\left({ }^{\circ}\right)$} \\
\hline $\mathrm{N}(2)-\mathrm{Co}(1)-\mathrm{Cl}(1)$ & & $138.69(13)$ & $128.39(11)$ \\
\hline $\mathrm{N}(3)-\mathrm{Co}(1)-\mathrm{Cl}(2)$ & & $95.53(13)$ & $92.68(11)$ \\
\hline $\mathrm{N}(1)-\mathrm{Co}(1)-\mathrm{Cl}(2)$ & & $102.02(12)$ & $102.93(11)$ \\
\hline $\mathrm{Cl}(2)-\mathrm{Co}(1)-\mathrm{Cl}(1)$ & & $116.45(6)$ & $118.97(6)$ \\
\hline$C(3)-N(2)-C(7)$ & $117.8(2)$ & $120.1(4)$ & $120.4(4)$ \\
\hline$C(2)-N(1)-C(15)$ & $119.7(2)$ & $121(2)$ & $121.3(4)$ \\
\hline$C(8)-N(3)-C(10)$ & $120.5(3)$ & $119.3(5)$ & $121.3(4)$ \\
\hline
\end{tabular}

'The atoms labeled with ' $\mathrm{A}$ ' have been generated by symmetry

\section{Catalytic properties evaluation}

To explore the capacity of Co1 - Co6 to act as precatalysts for ethylene polymerization, two different co-catalysts were assessed namely methylaluminoxane (MAO) and modified methylaluminoxane (MMAO). Indeed, both these types of 
aluminoxane have a longstanding reputation for being among the most effective co-catalysts in cobalt-mediated ethylene polymerization and, what is more, can be influential on the polymer properties. ${ }^{11 a, 16}$ Consequently, we conduct herein two parallel investigations using either MAO or MMAO to investigate the catalytic performance of all six precatalysts. Typically, these initial polymerization runs were performed at 10 atm $\mathrm{C}_{2} \mathrm{H}_{4}$ using a temperature-controlled reactor. All polymeric products were characterized by GPC and DSC while the distribution of any oligomeric fractions determined using GC.

(a) Ethylene polymerization using Co1 - Co6/MAO. Firstly, we explored Co1 as the test precatalyst with MAO as the cocatalyst to optimize the polymerization conditions as well as to explore the effect of various parameters on the polymerization performance; the results are collected in Table 2 . With the $\mathrm{Al}:$ Co molar ratio fixed at 1000 , the temperature was varied in 10 degree increments from 30 to $100{ }^{\circ} \mathrm{C}$ (runs $1-8$, Table 2). In all cases, mixtures of polymers and oligomers were obtained with their relative ratio dependent on the run temperature (Figure 4). The highest activity for ethylene oligomerization of $9.69 \times 10^{6} \mathrm{~g} \cdot \mathrm{mol}^{-1}(\mathrm{Co}) \cdot \mathrm{h}^{-1}$ was observed at $30^{\circ} \mathrm{C}$ (run 1, Table 2). By marked contrast, the highest activity for ethylene polymerization $\left(8.50 \times 10^{6} \mathrm{~g} \cdot \mathrm{mol}^{-1}(\mathrm{Co}) \cdot \mathrm{h}^{-1}\right)$ was achieved at 70 ${ }^{\circ} \mathrm{C}$ (run 5, Table 2). Significantly, this activity for polymerization exceeds that displayed by a range of structurally related mononuclear comparators and moreover this occurs at a higher operating temperature; findings that underline the temperature stability of these binuclear catalysts. ${ }^{1 a, 17}$

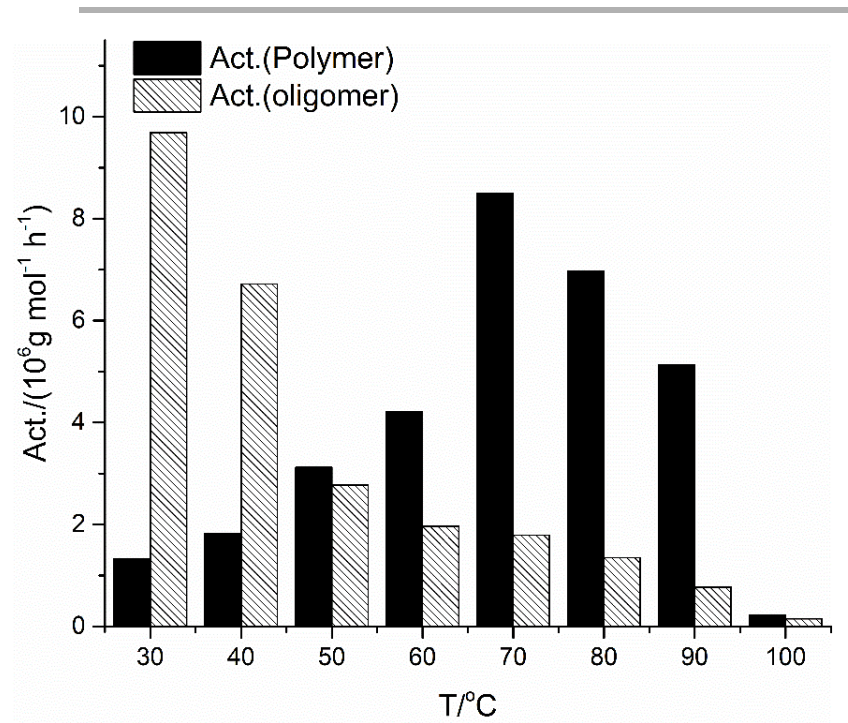

Figure 4 Polymerization versus oligomerization activity using Co1/MAO as a function of the run temperature (runs $1-8$, Table 2)

To the best of our knowledge, this is a rare example in which higher temperature leads to greater polymerization activity while lower temperature to better oligomerization activity. ${ }^{2,18}$ In terms of the polymer properties, the molecular weights are typical of polyethylene waxes ( $M_{\mathrm{w}}$ range: $\left.9.59-5.29 \mathrm{~kg} \mathrm{~mol}^{-1}\right)$ and decrease in their value on increasing the temperature from 30 to $60{ }^{\circ} \mathrm{C}$; likewise a reduction in dispersity is also observed in this temperature range. However, further elevating the temperature from 60 to $90{ }^{\circ} \mathrm{C}$ revealed no significant impact on the molecular weight nor to the dispersity (Figure 5), with the melting temperatures $\left(T_{\mathrm{m}}\right)$ of these polymers displaying little variation (123.8 - $\left.125.5{ }^{\circ} \mathrm{C}\right)$. These high temperature characteristics further emphasize the improved thermal stability of these binuclear cobalt complexes that are clearly capable of undergoing unaffected chain propagation at temperatures above $60{ }^{\circ} \mathrm{C}$. In terms of the oligomer composition, the selectivity towards $\alpha$-olefins was more than $99 \%$ and followed a Schulz-Flory distribution (Figure 6). As noted earlier an increase in the reaction temperature led to a decrease in the oligomerization activity, while the content of higher oligomers visibly increased $\left(\mathrm{C}_{10}\right.$ $C_{30}$ ) (Figure 6); comparable temperature effects on oligomer distributions are rare. ${ }^{5 c, 19}$

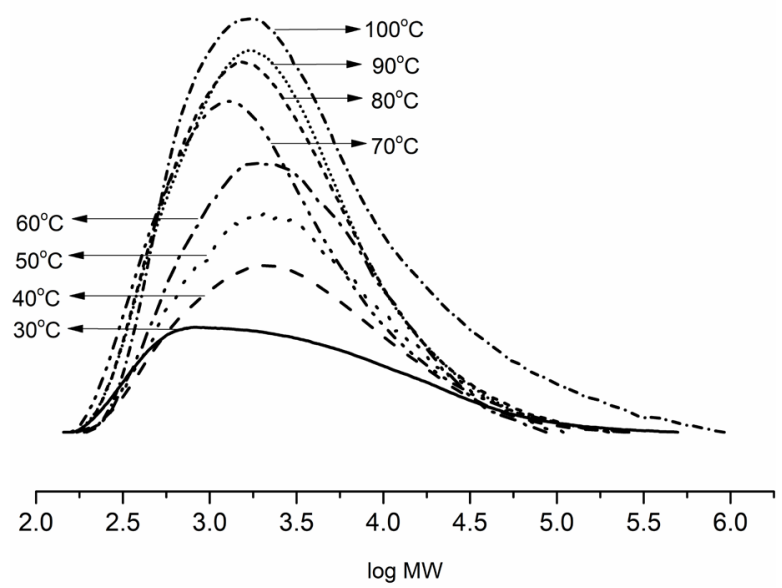

Figure 5 GPC curves of the polyethylene obtained using Co1/MAO at different run temperatures (runs 1 - 8, Table 2)

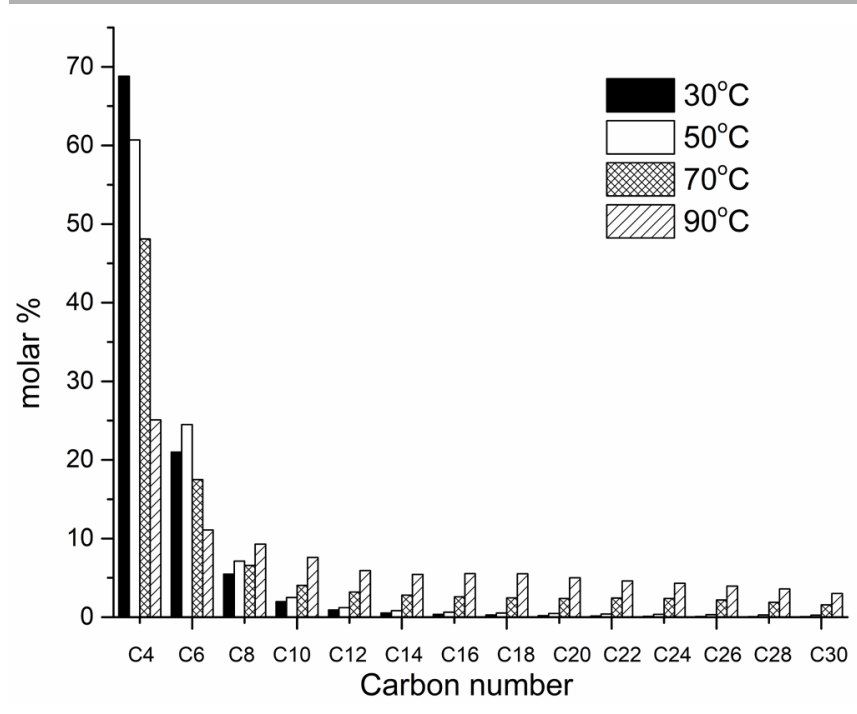

Figure 6 The distribution of $\alpha$-olefins produced using Co1/MAO as a function of the run temperature (runs 1, 3, 5, 7, Table 2) 
Table 2 Ethylene polymerization/oligomerization results obtained using Co1/MAO

\begin{tabular}{|c|c|c|c|c|c|c|c|c|c|c|c|c|c|c|}
\hline \multirow[b]{2}{*}{ Run } & \multirow[b]{2}{*}{$\mathrm{Al}: \mathrm{Co}$} & \multirow[b]{2}{*}{$\begin{array}{l}\mathrm{T} \\
\left({ }^{\circ} \mathrm{C}\right)\end{array}$} & \multirow[b]{2}{*}{$\begin{array}{l}\mathrm{t} \\
(\min )\end{array}$} & \multirow[b]{2}{*}{$\begin{array}{l}\text { Overall } \\
\text { activity }^{b, c}\end{array}$} & \multicolumn{4}{|c|}{ Polymer } & \multicolumn{6}{|c|}{ Oligomerg } \\
\hline & & & & & $\begin{array}{l}\text { Activity } \\
\text { (polym) }^{\mathrm{c}}\end{array}$ & $M_{w^{d, e}}$ & $M_{\mathrm{w}} / M_{\mathrm{n}}^{\mathrm{e}}$ & $T_{\mathrm{m}}^{\mathrm{f}}$ & $\begin{array}{l}\text { Activity } \\
\text { (olig)c }\end{array}$ & $\Sigma \mathrm{C}_{4} / \Sigma \mathrm{C}^{\mathrm{h}}$ & $\sum \mathrm{C}_{6} / \sum \mathrm{C}^{\mathrm{h}}$ & $\Sigma \mathrm{C}_{8} / \Sigma \mathrm{C}^{\mathrm{h}}$ & $>\sum \mathrm{C}_{8} / \sum \mathrm{C}^{\mathrm{h}}$ & $\begin{array}{l}\alpha- \\
\mathrm{C} / \Sigma \mathrm{C}^{\mathrm{h}}\end{array}$ \\
\hline 1 & 1000 & 30 & 30 & 11.0 & 1.32 & 9.59 & 7.62 & 125.4 & 9.69 & 68.8 & 21.0 & 5.48 & 4.72 & $>99$ \\
\hline 2 & 1000 & 40 & 30 & 8.54 & 1.82 & 7.09 & 4.60 & 125.5 & 6.72 & 61.9 & 26.2 & 7.41 & 4.49 & $>99$ \\
\hline 3 & 1000 & 50 & 30 & 5.89 & 3.12 & 6.20 & 3.95 & 125.5 & 2.77 & 60.7 & 24.5 & 7.12 & 7.68 & $>99$ \\
\hline 4 & 1000 & 60 & 30 & 6.17 & 4.21 & 5.29 & 3.39 & 125.2 & 1.96 & 57.0 & 25.3 & 7.93 & 9.77 & $>99$ \\
\hline 5 & 1000 & 70 & 30 & 10.3 & 8.50 & 5.41 & 4.77 & 123.8 & 1.79 & 48.1 & 17.5 & 6.57 & 27.8 & $>99$ \\
\hline 6 & 1000 & 80 & 30 & 8.32 & 6.97 & 5.58 & 4.24 & 124.5 & 1.35 & 30.3 & 19.6 & 9.86 & 40.2 & $>99$ \\
\hline 7 & 1000 & 90 & 30 & 5.90 & 5.13 & 5.60 & 4.18 & 124.9 & 0.77 & 25.1 & 11.1 & 9.30 & 54.5 & $>99$ \\
\hline 8 & 1000 & 100 & 30 & 0.37 & 0.22 & 15.0 & 9.15 & 126.7 & 0.15 & 25.8 & 16.5 & 9.80 & 47.9 & $>99$ \\
\hline 9 & 750 & 70 & 30 & 7.06 & 5.31 & 6.39 & 4.08 & 125.8 & 1.75 & 49.9 & 22.5 & 8.38 & 19.3 & $>99$ \\
\hline 10 & 1250 & 70 & 30 & 8.36 & 6.59 & 5.74 & 3.81 & 125.9 & 1.77 & 51.3 & 22.3 & 8.49 & 17.9 & $>99$ \\
\hline 11 & 1500 & 70 & 30 & 7.19 & 5.47 & 5.44 & 3.60 & 125.8 & 1.72 & 49.8 & 26.0 & 8.61 & 15.6 & $>99$ \\
\hline 12 & 2000 & 70 & 30 & 6.51 & 5.10 & 4.52 & 3.01 & 126.0 & 1.41 & 59.0 & 22.5 & 6.56 & 11.9 & $>99$ \\
\hline 13 & 1000 & 70 & 5 & 18.7 & 13.3 & 4.97 & 3.28 & 125.2 & 5.44 & 48.6 & 25.7 & 8.98 & 16.7 & $>99$ \\
\hline 14 & 1000 & 70 & 15 & 12.8 & 9.43 & 5.41 & 3.55 & 125.2 & 3.33 & 49.5 & 23.5 & 8.41 & 18.6 & $>99$ \\
\hline 15 & 1000 & 70 & 45 & 7.97 & 6.00 & 5.61 & 3.75 & 125.2 & 1.97 & 45.8 & 22.8 & 8.69 & 22.7 & $>99$ \\
\hline 16 & 1000 & 70 & 60 & 6.19 & 4.67 & 8.27 & 5.17 & 126.1 & $1 . .52$ & 34.0 & 18.2 & 8.88 & 38.9 & $>99$ \\
\hline $17^{i}$ & 1000 & 70 & 30 & 0.13 & 0.13 & 3.88 & 2.60 & 124.6 & Trace & & & & & \\
\hline $18^{\mathrm{j}}$ & 1000 & 70 & 30 & 4.88 & 3.93 & 4.59 & 2.92 & 125.2 & 0.95 & 41.7 & 22.7 & 9.69 & 25.9 & $>99$ \\
\hline
\end{tabular}

${ }^{a}$ General conditions: $1.5 \mu \mathrm{mol}$ of $\mathrm{Co1}, 10 \mathrm{~atm} \mathrm{C}_{2} \mathrm{H}_{4}, 100 \mathrm{~mL}$ of toluene.

${ }^{\mathrm{b}}$ Overall activity = activity (polym) + activity (olig).

${ }^{c}$ In units of $10^{6} \mathrm{~g} \cdot \mathrm{mol}^{-1}(\mathrm{Co}) \cdot \mathrm{h}^{-1}$.

${ }^{\mathrm{d}}$ In units of $\mathrm{kg} \mathrm{mol}^{-1}$.

e Determined by GPC.

${ }^{\mathrm{f}}$ Determined by DSC; in units of ${ }^{\circ} \mathrm{C}$.

g Determined by GC.

${ }^{\mathrm{h}} \sum \mathrm{C}_{4}, \sum \mathrm{C}_{6}, \sum \mathrm{C}_{8}$, and $\sum \mathrm{C}$ denote the total amounts of butene, hexene, octene and oligomers in mol\%, respectively.

i $1 \mathrm{~atm} \mathrm{C}_{2} \mathrm{H}_{4}$.

j 5 atm $\mathrm{C}_{2} \mathrm{H}_{4}$.

Based on these variations in performance characteristics noted with temperature, it would seem likely that two kinds of active species are operational using Co1/MAO. On increasing the temperature, the binuclear cobalt catalyst tends to form catalytic active sites which can mediate the conversion of ethylene to higher molecular weight polyethylene while at lower temperature, the formation of oligomer becomes prevalent. It is uncertain as to the origin of these differences in behavior but may be due to the configuration of the cobalt sites in the active species. Some insight can be gained by consideration of the relative configurations of the $(N, N, N) \mathrm{CoCl}_{2}$ units in the precatalyst (Figure 7). Inspection of the molecular structures of $\mathrm{Co3}$ and $\mathrm{Co5}$ reveals these two units to adopt an anti-configuration. However, it would seem plausible that some rotation about the $\mathrm{N}-\mathrm{C}$ bonds involving the naphthyl linker in the precatalyst can occur at higher temperature so as to form the syn-configured arrangement. Likewise, a synconfiguration could be generated in the active catalyst at higher temperature leading to the two active centers being held in closer proximity with the overall effect that chain propagation is promoted.
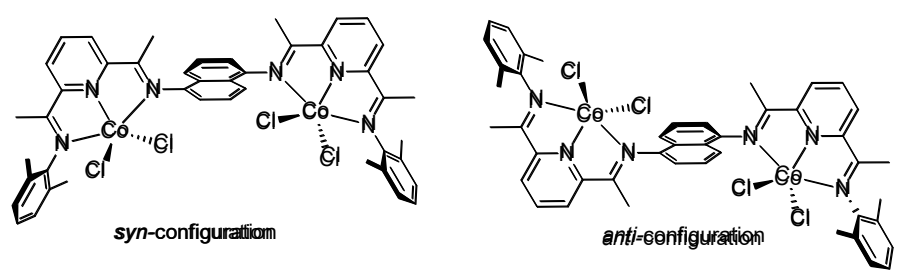

Figure 7 Relative configuration of the two $(N, N, N) \mathrm{CoCl}_{2}$ units in $\mathrm{Co1}$

With the focus on forming predominantly polymer, the temperature was kept at $70{ }^{\circ} \mathrm{C}$ and the amount of MAO investigated by varying the molar ratio of Al:Co from 750 to 2000 (runs 5, $9-12$, Table 2). The best activity for polymerization of $8.50 \times 10^{6} \mathrm{~g} \cdot \mathrm{mol}^{-1}(\mathrm{Co}) \cdot \mathrm{h}^{-1}$ was viewable at 1000 ; the level of oligomerization albeit lower $\left(1.79 \times 10^{6}\right.$ $\mathrm{g} \cdot \mathrm{mol}^{-1}(\mathrm{Co}) \cdot \mathrm{h}^{-1}$ ) was also seen to peak at this molar ratio. In terms of the polymer properties, the molecular weight as well as the dispersity did not change significantly $(4.52-6.39 \mathrm{~kg}$ $\mathrm{mol}^{-1}, M_{\mathrm{w}} / M_{\mathrm{n}}=3.01-4.77$ ) (Figure 8 ). The broadness of some of the distributions could plausibly be attributed to the 
presence of multiple active sites and/or the presence of different termination pathways. In the same way, the activity and the distribution of the oligomers showed little variation as the molar ratio was varied.

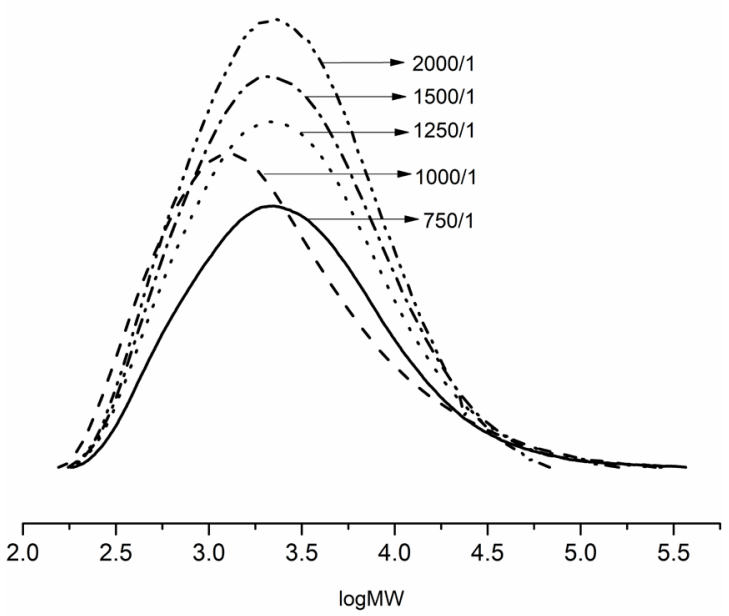

Figure 8 GPC curves of the polyethylene obtained using Co1/MAO at different Al:Co molar ratios (runs 5, 9-12, Table 2)

In addition, the effect of ethylene pressure was investigated by fixing the temperature at $70{ }^{\circ} \mathrm{C}$ and the $\mathrm{Al}: \mathrm{Co}$ ratio at 1000 (runs 5, 17,18, Table 2). As expected, a noticeable drop in activity was observed when the pressure was lowered from 10 atm to initially 5 atm and then more dramatically as the pressure was reduced to $1 \mathrm{~atm}$, such observations are in line with a suppression in the rate of propagation at lower ethylene pressure. ${ }^{15}$ Moreover, the molecular weight of the resultant polyethylenes remained essentially invariant across the three pressure regimes, suggesting the chain propagation and $6-\mathrm{H}$ elimination to metal or to monomer decreased equally as the ethylene pressure was reduced. ${ }^{14 a, 20}$
With the Al:Co molar ratio retained at 1000 and the run temperature at $70{ }^{\circ} \mathrm{C}$, the effect of run time on the performance of Co1/MAO was examined by conducting the reactions at intervals between 5 and 60 min (runs 5, 13-16, Table 2). The overall catalytic activity of Co1/MAO decreased from $18.7 \times 10^{6} \mathrm{~g} \cdot \mathrm{mol}^{-1}(\mathrm{Co}) \cdot \mathrm{h}^{-1}$ after $5 \mathrm{~min}$ to $6.19 \times 10^{6} \mathrm{~g} \cdot \mathrm{mol}-$ ${ }^{1}(\mathrm{Co}) \cdot \mathrm{h}^{-1}$ at the $60 \mathrm{~min}$ mark in agreement with some deactivation of the active species. ${ }^{21}$ Nevertheless the activity of Co1/MAO even after 60 min can be regarded as good which highlights the appreciable catalytic lifetime of the active species. It is also worthy of note that both the activity for polymerization and oligomerization reached their highest values at $5 \mathrm{~min}\left[13.3 \times 10^{6} \mathrm{~g} \cdot \mathrm{mol}^{-1}(\mathrm{Co}) \cdot \mathrm{h}^{-1}\right.$ for polymerization and $5.44 \times 10^{6} \mathrm{~g} \cdot \mathrm{mol}^{-1}(\mathrm{Co}) \cdot \mathrm{h}^{-1}$ for oligomerization]. With regard to the polymer, the molecular weight and the dispersity increased over longer run times while for the oligomers only modest changes were observed with the content of $>\mathrm{C}_{8}$ up to $38.9 \%$ after $60 \mathrm{~min}$.

To investigate the effects of ligand structure on the catalytic properties, the remaining five cobalt precatalysts, Co2 - Co6, were also evaluated in combination with MAO under the optimized condition established for $\mathrm{Co1}$ [Al:Co ratio $=1000$, run temperature $=70^{\circ} \mathrm{C}, 10 \mathrm{~atm} \mathrm{C}_{2} \mathrm{H}_{4}$, reaction time $30 \mathrm{~min}$ ] (runs, $2-6$, Table 3 ). Inspection of the data reveals the overall activity to decrease in the order: $\operatorname{Co} 1\left[2,6-\mathrm{Me}_{2}\right]>\operatorname{Co} 4[2,4,6-$ $\left.\mathrm{Me}_{3}\right]>\operatorname{Co} 3\left[2,6-{ }^{i} \mathrm{Pr}_{2}\right]>\operatorname{Co} 5\left[2,6-\mathrm{Et}_{2}-4-\mathrm{Me}\right]>\operatorname{Co} 2\left[2,6-\mathrm{Et}_{2}\right]>\mathrm{Co} 6$ $\left[2,6-\mathrm{CHPh}_{2}-4-\mathrm{Me}\right]$. This implies that the steric properties of the exterior $\mathrm{N}$-aryl groups have a distinct impact on catalytic performance with the activities decreasing from $10.3 \times 10^{6}$ $\mathrm{g} \cdot \mathrm{mol}^{-1}(\mathrm{Co}) \cdot \mathrm{h}^{-1}$ for the least bulky $\operatorname{Co1}\left(\mathrm{R}^{1}=\mathrm{Me}\right)$ to $2.81 \times 10^{6}$ $\mathrm{g} \cdot \mathrm{mol}^{-1}(\mathrm{Co}) \cdot \mathrm{h}^{-1}$ for the most bulky $\operatorname{Co6}\left(\mathrm{R}^{1}=\mathrm{CHPh}_{2}\right) \cdot{ }^{16,22}$ On the other hand, the effect of para-methyl substitution on activity is less clear with $\mathrm{Co}$ [2,6- $\left.\mathrm{Me}_{2}\right]>\mathrm{Co} 4$ [2,4,6-Me $]$ while $\mathrm{Co}$ [2,6$\left.\mathrm{Et}_{2}-4-\mathrm{Me}\right]>\operatorname{Co} 2\left[2,6-\mathrm{Et}_{2}\right]$. All systems formed mixtures of oligomers and polymers though for Co6, polymer represented the main component of product distribution. With regard to

Table 3 Ethylene polymerization/oligomerization results obtained using Co1 - Co6/MAO

\begin{tabular}{|c|c|c|c|c|c|c|c|c|c|c|c|c|}
\hline \multirow[b]{2}{*}{ Run } & \multirow[b]{2}{*}{ Precat. } & \multirow[b]{2}{*}{$\begin{array}{l}\text { Overall } \\
\text { activity }^{b, c}\end{array}$} & \multicolumn{4}{|c|}{ Polymer } & \multicolumn{6}{|c|}{ Oligomerg } \\
\hline & & & $\begin{array}{l}\text { Activity } \\
\text { (polym) }^{\mathrm{c}}\end{array}$ & $M_{\mathrm{w}}^{\mathrm{d}, \mathrm{e}}$ & $M_{\mathrm{w}} / M_{\mathrm{n}}^{\mathrm{e}}$ & $T_{\mathrm{m}}^{\mathrm{f}}$ & $\begin{array}{l}\text { Activity } \\
\text { (olig) }^{c}\end{array}$ & $\sum \mathrm{C}_{4} / \sum \mathrm{C}^{\mathrm{h}}$ & $\sum \mathrm{C}_{6} / \sum \mathrm{C}^{\mathrm{h}}$ & $\sum \mathrm{C}_{8} / \sum \mathrm{C}^{\mathrm{h}}$ & $>\Sigma \mathrm{C}_{8} / \Sigma \mathrm{C}^{\mathrm{h}}$ & $\begin{array}{l}\alpha- \\
\mathrm{C} / \Sigma \mathrm{C}^{\mathrm{h}}\end{array}$ \\
\hline 1 & Co1 & 10.3 & 8.50 & 5.41 & 4.77 & 123.8 & 1.79 & 48.1 & 17.5 & 6.57 & 27.8 & $>99$ \\
\hline 2 & Co2 & 3.20 & 2.65 & 9.76 & 3.79 & 130.8 & 0.55 & 32.6 & 17.5 & 9.9 & 40.0 & $>99$ \\
\hline 3 & $\mathrm{Co3}$ & 4.94 & 4.31 & 17.0 & 3.77 & 132.3 & 0.63 & 23.8 & 16.8 & 8.24 & 51.2 & $>99$ \\
\hline 4 & Co4 & 7.49 & 5.47 & 6.77 & 4.75 & 126.3 & 2.02 & 25.0 & 15.0 & 9.80 & 50.2 & $>99$ \\
\hline 5 & Co5 & 4.51 & 2.82 & 10.5 & 4.32 & 128.6 & 1.69 & 37.8 & 21.8 & 14.3 & 26.1 & $>99$ \\
\hline 6 & Co6 & 2.81 & 2.81 & 247 & 39.5 & 134.3 & Trace & & & & & \\
\hline
\end{tabular}

${ }^{\text {a }}$ Conditions: $1.5 \mu \mathrm{mol}$ of cobalt precatalyst, $10 \mathrm{~atm} \mathrm{C}_{2} \mathrm{H}_{4}$, total volume $100 \mathrm{~mL}, 70{ }^{\circ} \mathrm{C}$ run temperature, $\mathrm{Al}: \mathrm{Co}$ ratio $=1000$

b Overall activity = activity (polym) + activity (olig).

${ }^{c}$ In units of $10^{6} \mathrm{~g}(\mathrm{PE}) \cdot \mathrm{mol}^{-1}(\mathrm{Co}) \cdot \mathrm{h}^{-1}$. ${ }^{\mathrm{d}}$ In units of $\mathrm{kg} \mathrm{mol}^{-1}$.

${ }^{\mathrm{e}}$ Determined by GPC. ${ }^{\mathrm{f}}$ Determined by DSC; in units of ${ }^{\circ} \mathrm{C}$.

g Determined by $\mathrm{GC}$;

${ }^{h} \sum C_{4}, \sum C_{6}, \sum C_{8}$ and $\sum C$ denote the total amounts of butene, hexene, octene and oligomers in mol\%, respectively 

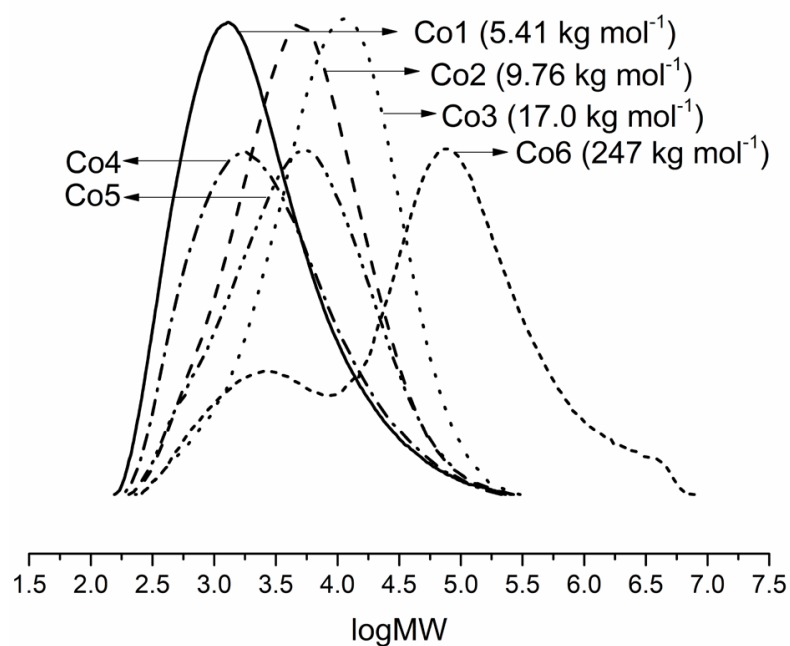

Figure 9 GPC traces of the polymers obtained using Co1 - Co6/MAO (runs $1-6$, Table 3 ).

the molecular weight of the polyethylenes, steric effects also play a key role. For example, when increasing the steric properties of the ortho- $\mathrm{R}^{1}$-substituents successively from Me to $\mathrm{Et}$ to ${ }^{\mathrm{P} r}$ to $\mathrm{CHPh}_{2}$, the molecular weight of the polyethylene in-turn progressively increased (Figure 9). Indeed, high molecular weight polyethylene $\left(246.7 \mathrm{~kg} \mathrm{~mol}^{-1}\right)$ was obtained using the most sterically encumbered benzhydryl derivative, Co6, and what is more with a broad bimodal distribution.

In general the polyethylenes obtained using Co1 Co6/MAO displayed $T_{\mathrm{m}}$ 's of between 123.8 and $134.4{ }^{\circ} \mathrm{C}$, values that are quite typical of highly linear materials (runs 1 6 , Table 3). To examine the microstructural properties of these polymers, a representative sample generated using Co1/MAO [run $1\left(70^{\circ} \mathrm{C}\right)$, Table 3] was characterized by high temperature

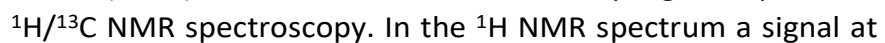
$\delta 1.37$ could be clearly seen for the $-\left(\mathrm{CH}_{2}\right)_{n}$ - repeat unit of a

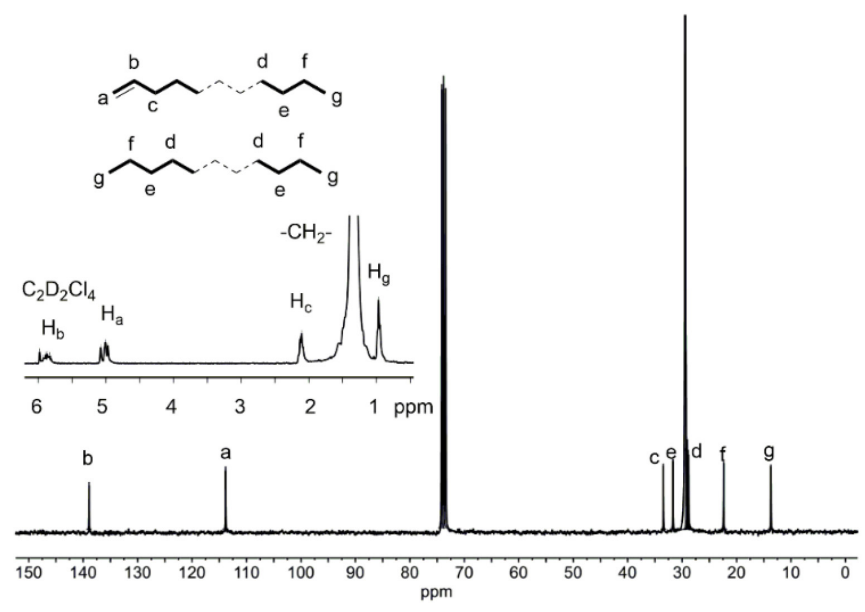

This journal is (C) The Royal Society of Chemistry 20xx
Figure $10{ }^{13} \mathrm{C}$ NMR spectrum of the polyethylene obtained in run 1 (Table 3) using Co1/MAO ( $\delta \subset 73.8$, tetrachloroethane- $d_{2}$ ); an insert of its ${ }^{1} \mathrm{H}$ NMR spectrum is also given.

linear polymer (Figure 10). In addition, weaker downfield signals at $\delta 5.88$ and 5.02 in a 1:2 ratio can be assigned to a vinyl group. ${ }^{23}$ This was further confirmed by the ${ }^{13} \mathrm{C} N M R$ spectrum with the corresponding vinylic carbon signals visible at $\delta 138.9$ and $113.8 .{ }^{23}$ Furthermore, the relative ratio of the integrals for the $\mathrm{H}_{\mathrm{g}} / \mathrm{H}_{\mathrm{b}}$ protons belonging to the end groups was about $4: 1$, implying the presence of some fully saturated polyethylene.

To investigate the effects of temperature on the content of vinyl-end groups, three other samples obtained using Co1/MAO at different run temperatures [runs $1\left(30^{\circ} \mathrm{C}\right), 3(50$ $\left.{ }^{\circ} \mathrm{C}\right), 7\left(90{ }^{\circ} \mathrm{C}\right)$, Table 2] were also characterized by ${ }^{1} \mathrm{H}$ NMR spectroscopy (Figures $\mathrm{S} 1-\mathrm{S} 2, \mathrm{~S} 4$ ). Examination of the integral ratios for their $\mathrm{H}_{\mathrm{g}} / \mathrm{H}_{\mathrm{b}}$ protons, revealed that on increasing the run temperature, the percentage of vinyl-end groups increased from 68 to $91 \%$. This would suggest that $8-\mathrm{H}$ elimination to metal or to monomer becomes the main chain transfer pathway as the temperature was raised.11a,15,16c

(b) Ethylene polymerization using Co1 - Co6/MMAO. To supplement the investigation undertaken with MAO, a separate study using MMAO was also conducted to assess the performance of Co1 - Co6; the results are gathered in Table 3. As with MAO study, the performance of Co1/MMAO was initially investigated by screening it at different temperatures between 30 and $100{ }^{\circ} \mathrm{C}$ with the Al:Co molar ratio of 1000,10 atm ethylene pressure and run time fixed $30 \mathrm{~min}$, respectively (runs $1-8$, Table 4). Once again both polymers and oligomers were a feature of the reaction mixture with their relative ratio affected by the temperature. Hence, the highest polymerization catalytic activity of $6.51 \times 10^{6} \mathrm{~g} \cdot \mathrm{mol}^{-1}(\mathrm{Co}) \cdot \mathrm{h}^{-1}$ was obtained at $80^{\circ} \mathrm{C}$ (Figure 11), while for oligomerization this was noted at $30{ }^{\circ} \mathrm{C}\left(5.53 \times 10^{6} \mathrm{~g} \cdot \mathrm{mol}^{-1}(\mathrm{Co}) \cdot \mathrm{h}^{-1}\right)$. In terms of the polymerization

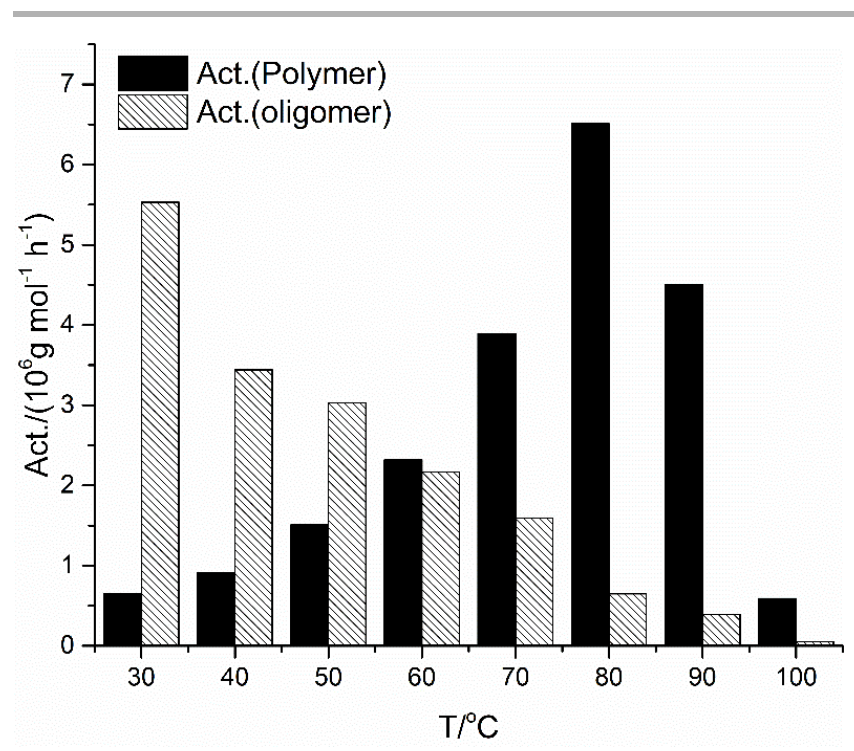

Figure 11 Polymerization versus oligomerization activity using 
Co1/MMAO as a function of the run temperature (runs $1-8$, Table

4).

Table 4 Ethylene polymerization/oligomerization results obtained using Co1/MMAOa

\begin{tabular}{|c|c|c|c|c|c|c|c|c|c|c|c|c|c|c|}
\hline \multirow[b]{2}{*}{ Run } & \multirow[b]{2}{*}{$\mathrm{Al}: \mathrm{Co}$} & \multirow[b]{2}{*}{$\begin{array}{l}\mathrm{T} \quad( \\
\left.{ }^{\circ} \mathrm{C}\right)\end{array}$} & \multirow[b]{2}{*}{$\begin{array}{l}\mathrm{t} \\
(\min )\end{array}$} & \multirow[b]{2}{*}{$\begin{array}{l}\text { Overall } \\
\text { activity }^{\mathrm{b}, \mathrm{c}}\end{array}$} & \multicolumn{4}{|c|}{ Polymer } & \multicolumn{6}{|c|}{ Oligomer ${ }^{g}$} \\
\hline & & & & & $\begin{array}{l}\text { Activity } \\
(\text { polym) }\end{array}$ & $M_{w^{d, e}}$ & $M_{\mathrm{w}} / M_{\mathrm{n}}^{\mathrm{e}}$ & $T_{\mathrm{m}}^{f}$ & $\begin{array}{l}\text { Activity } \\
\text { (olig) }^{c}\end{array}$ & $\Sigma \mathrm{C} 4 / \sum \mathrm{Ch}^{\mathrm{h}}$ & $\sum \mathrm{C} 6 / \sum \mathrm{Ch}^{\mathrm{h}}$ & $\Sigma \mathrm{C} 8 / \sum \mathrm{Ch}^{\mathrm{h}}$ & $>\Sigma \mathrm{C} 8 / \Sigma \mathrm{C}^{\mathrm{h}}$ & $\begin{array}{l}\alpha- \\
\mathrm{C} / \Sigma \mathrm{C}^{\mathrm{h}}\end{array}$ \\
\hline 1 & 1000 & 30 & 30 & 6.18 & 0.65 & 4.19 & 3.15 & 124.3 & 5.53 & 65.6 & 22.8 & 8.45 & 3.15 & $>99$ \\
\hline 2 & 1000 & 40 & 30 & 4.35 & 0.91 & 5.41 & 3.33 & 125.6 & 3.44 & 63.9 & 25.2 & 7.53 & 3.37 & $>99$ \\
\hline 3 & 1000 & 50 & 30 & 4.54 & 1.51 & 4.67 & 3.31 & 124.4 & 3.03 & 62.3 & 27.7 & 6.41 & 3.59 & $>99$ \\
\hline 4 & 1000 & 60 & 30 & 4.49 & 2.32 & 3.98 & 2.88 & 124.7 & 2.17 & 59.3 & 26.9 & 8.25 & 5.55 & $>99$ \\
\hline 5 & 1000 & 70 & 30 & 5.48 & 3.89 & 3.81 & 2.79 & 124.6 & 1.59 & 57.6 & 22.1 & 6.68 & 13.8 & $>99$ \\
\hline 6 & 1000 & 80 & 30 & 7.16 & 6.51 & 3.29 & 2.48 & 123.9 & 0.65 & 20.8 & 13.3 & 8.23 & 57.7 & $>99$ \\
\hline 7 & 1000 & 90 & 30 & 4.89 & 4.50 & 3.88 & 2.87 & 124.2 & 0.39 & 20.6 & 13.1 & 9.63 & 56.7 & $>99$ \\
\hline 8 & 1000 & 100 & 30 & 0.64 & 0.59 & 18.1 & 8.06 & 127.9 & 0.05 & 28.8 & 15.0 & 14.4 & 41.8 & $>99$ \\
\hline 9 & 750 & 80 & 30 & 4.94 & 4.37 & 3.38 & 2.49 & 124.2 & 0.57 & 20.8 & 11.5 & 7.31 & 60.4 & $>99$ \\
\hline 10 & 1250 & 80 & 30 & 6.69 & 5.84 & 3.05 & 2.32 & 124.3 & 0.85 & 24.3 & 12.1 & 7.84 & 55.8 & $>99$ \\
\hline 11 & 1500 & 80 & 30 & 5.23 & 4.70 & 3.13 & 2.43 & 124.3 & 0.53 & 64.5 & 18.9 & 0.66 & 15.9 & $>99$ \\
\hline 12 & 2000 & 80 & 30 & 3.51 & 3.28 & 3.28 & 2.62 & 123.7 & 0.23 & 44.4 & 20.4 & 6.66 & 28.5 & $>99$ \\
\hline 13 & 1000 & 80 & 5 & 15.0 & 12.4 & 3.57 & 2.60 & 124.2 & 2.60 & 37.7 & 22.2 & 9.10 & 31.0 & $>99$ \\
\hline 14 & 1000 & 80 & 15 & 9.36 & 8.28 & 3.53 & 2.63 & 124.4 & 1.08 & 25.6 & 11.2 & 6.21 & 57.0 & $>99$ \\
\hline 15 & 1000 & 80 & 45 & 5.43 & 4.54 & 3.50 & 2.76 & 124.0 & 0.89 & 30.3 & 13.9 & 7.83 & 48.0 & $>99$ \\
\hline 16 & 1000 & 80 & 60 & 4.79 & 4.14 & 3.22 & 2.41 & 124.2 & 0.65 & 42.6 & 10.1 & 4.62 & 42.7 & $>99$ \\
\hline $17^{i}$ & 1000 & 80 & 30 & Trace & Trace & & & & Trace & & & & & \\
\hline $18^{\mathrm{j}}$ & 1000 & 80 & 30 & 2.47 & 2.34 & 3.77 & 2.68 & 124.7 & 0.13 & 36.1 & 6.98 & 22.7 & 34.2 & $>99$ \\
\hline
\end{tabular}

${ }^{\mathrm{a}}$ Conditions: $1.5 \mu \mathrm{mol}$ of Co1, $10 \mathrm{~atm} \mathrm{C}_{2} \mathrm{H}_{4}, 100 \mathrm{~mL}$ of toluene.

${ }^{\mathrm{b}}$ Overall activity = activity (polym) + activity (olig).

${ }^{c}$ In units of $\times 10^{6} \mathrm{~g}(\mathrm{PE}) \cdot \mathrm{mol}^{-1}(\mathrm{Co}) \cdot \mathrm{h}^{-1}$.

${ }^{\mathrm{d}}$ In units of $\mathrm{kg} \mathrm{mol}^{-1}$.

e Determined by GPC.

${ }^{f}$ Determined by DSC; in units of ${ }^{\circ} \mathrm{C}$.

${ }^{\mathrm{g}}$ Determined by GC.

${ }^{\mathrm{h}} \sum \mathrm{C}_{4}, \sum \mathrm{C}_{6}, \sum \mathrm{C}_{8}$ and $\sum \mathrm{C}$ denote the total amounts of butene, hexene, octene and oligomers in mol\%, respectively.

i 1 atm $\mathrm{C}_{2} \mathrm{H}_{4}$.

j 5 atm $\mathrm{C}_{2} \mathrm{H}_{4}$.

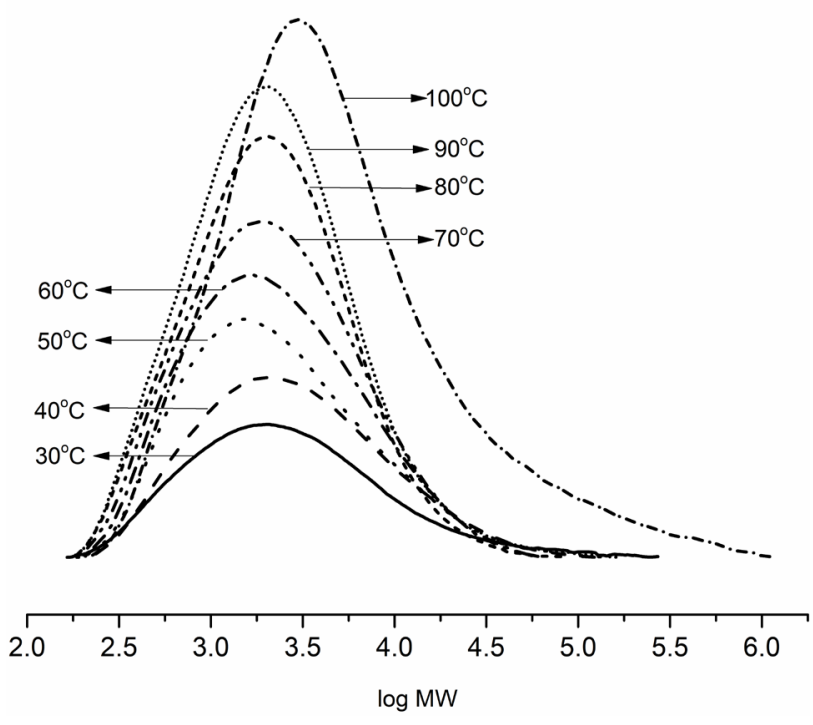

Figure 12 GPC traces of the polyethylene obtained using Co1/MMAO at different run temperatures (runs $1-8$, Table 4)

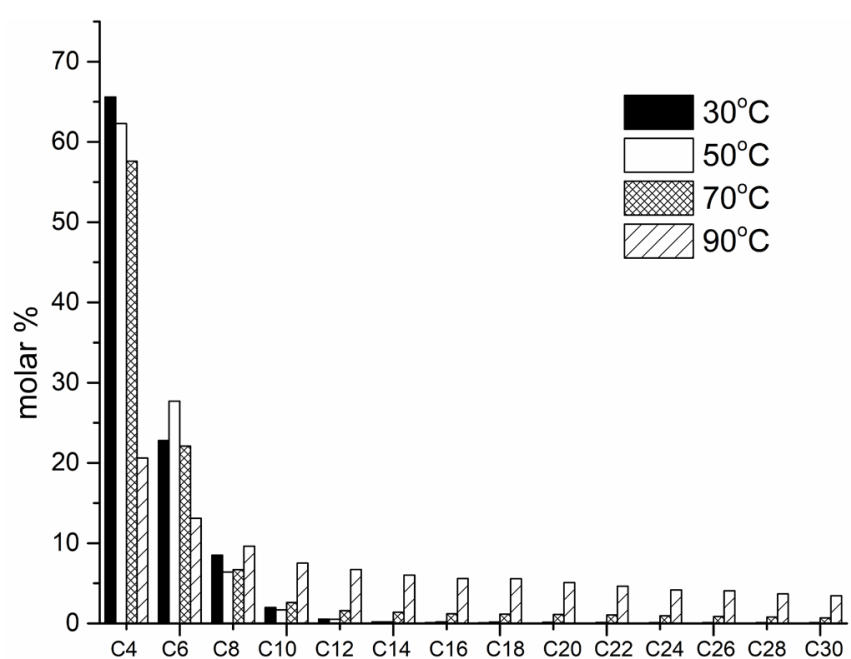

Carbon number

Figure 13 The distribution of $\alpha$-olefins produced using Co1/MMAO as a function of the run temperature (runs 1, 3, 5 and 7, Table 4). 


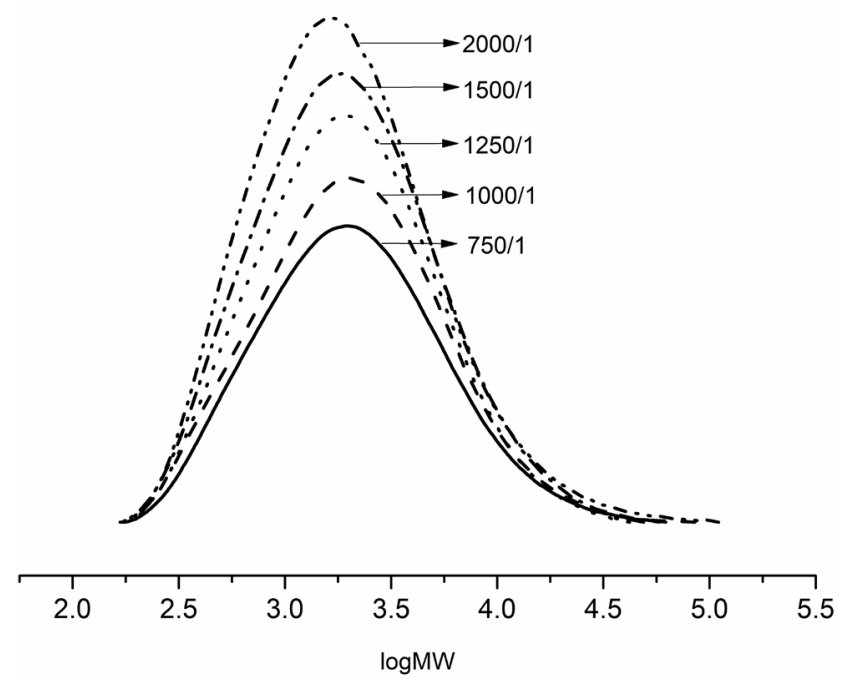

Figure $14 \mathrm{GPC}$ traces of the polyethylene obtained using Co1/MMAO at different Al:Co molar ratios (runs 5, 9-12, Table 4).

performance, Co1/MMAO showed better thermal stability than that seen with Co1/MAO (optimal temperature: 80 vs. 70 ${ }^{\circ} \mathrm{C}$ ) but the optimal activity was lower. As to the polymer properties, the molecular weight and dispersity of the polyethylene, showed little variation, except when the run temperature reached $100{ }^{\circ} \mathrm{C}\left(3.29-5.41 \mathrm{~kg} \mathrm{~mol}^{-1}\right.$, Figure 12) at which point an unexpected spike in molecular weight and dispersity was observed (run 8 , Table 4). With regard to the oligomeric product, a broad distribution between $C_{4}$ and $C_{30}$ was evident at $30^{\circ} \mathrm{C}$ that varied as the temperature was raised with the lower molecular weight fraction $\left(<\mathrm{C}_{10}\right)$ gradually decreasing and the higher molecular weight content becoming more significant (Figure 13). In all cases, the oligomers followed Schulz-Flory distributions with the selectivity towards $\alpha$-olefins exceeding $99 \%$.

Subsequently, the influence of Al:Co molar ratio on the performance of Co1/MMAO was investigated by varying it from 750 to 2000 (runs 6, 9-12, Table 4). The highest overall activity of $7.16 \times 10^{6} \mathrm{~g} \cdot \mathrm{mol}^{-1}(\mathrm{Co}) \cdot \mathrm{h}^{-1}$ was obtained at an Al:Co ratio of 1000 . The molecular weight of the resulting polyethylene showed no significant differences (3.05 - 3.38 kg $\mathrm{mol}^{-1}$ ) with fairly narrow unimodal molecular weight distributions a feature across the various ratios (Figure 14).

As regards the reaction time, the performance of Co1/MMAO was evaluated by conducting the runs over 5,15 , 30, 45 and $60 \mathrm{~min}$ (runs 6, 13-16, Table 4). The results indicate that the overall activity of Co1 decreased from $15.0 \times 10^{6}$ $\mathrm{g} \cdot \mathrm{mol}^{-1}(\mathrm{Co}) \cdot \mathrm{h}^{-1}$ after $5 \mathrm{~min}$ to $4.79 \times 10^{6} \mathrm{~g} \cdot \mathrm{mol}^{-1}(\mathrm{Co}) \cdot \mathrm{h}^{-1}$ after 60 min. As with the MAO runs, both the level of oligomerization and polymerization attained their highest values after $5 \mathrm{~min}$ $\left[12.4 \times 10^{6} \mathrm{~g} \cdot \mathrm{mol}^{-1}(\mathrm{Co}) \cdot \mathrm{h}^{-1}\right.$ for polymerization, $2.60 \times 10^{6} \mathrm{~g} \cdot \mathrm{mol}$ ${ }^{1}(\mathrm{Co}) \cdot \mathrm{h}^{-1}$ for oligomerization]. Likewise, variations in ethylene pressure had significant effects on activity with a lowering of pressure resulting in a downward trend in activity (runs 6,17 , 18, Table 4).

To investigate the effect of structural changes on the catalytic activity and polymer properties, Co2 - Co6 were additionally evaluated under the optimized conditions determined for Co1/MMAO (Al:Co molar ratio $=1000$, run temperature $=80^{\circ} \mathrm{C}$ ); the results are compiled in Table 5 and discussed alongside those recorded for Co1. The activity of the six cobalt complexes decreased in the order: $\mathrm{Co} 4\left[2,4,6-\mathrm{Me}_{3}\right]>$ $\operatorname{Co} 1\left[2,6-\mathrm{Me}_{2}\right]>\operatorname{Co} 3\left[2,6-{ }^{i} \mathrm{Pr}_{2}\right]>\operatorname{Co} 2\left[2,6-\mathrm{Et}_{2}\right]>\operatorname{Co}$ [2,6-Et $2-4-$ $\mathrm{Me}]>\operatorname{Co} 6\left[2,6-\mathrm{CHPh}_{2}-4-\mathrm{Me}\right]$. This order shows some similarities to that seen with MAO with the least bulky systems the most active and most bulky the least active. However, it is worth pointing out that the activities were generally less than those achieved with MAO as the co-catalyst and also fall in a narrower range with values between 2.44 and $7.16 \times 10^{6}$ $\mathrm{g} \cdot \mathrm{mol}^{-1}(\mathrm{Co}) \cdot \mathrm{h}^{-1}$. Nonetheless, the molecular weight of the polyethylene rapidly increased $\left(3.29,6.84,18.6,261 \mathrm{~kg} \mathrm{~mol}^{-1}\right)$ as the steric properties of the ortho- $\mathrm{R}^{1}$ substituents were increased progressively from Me to Et to ${ }^{i} \mathrm{Pr}$ to $\mathrm{CHPh}_{2}$ (Figure 15). As a further point, the polyethylenes generally showed narrower distributions $\left(M_{\mathrm{w}} / M_{\mathrm{n}}=2.10-3.18\right)$ when compared with the MAO runs with the broadest displayed using Co6 $\left(M_{\mathrm{w}} / M_{\mathrm{n}}=13.2\right)$.

As is common to all runs, the polymers obtained using Co1 - Co6/MAO displayed $T_{\mathrm{m}}$ 's that were characteristic of highly linear materials. This was confirmed in the ${ }^{1} \mathrm{H}$ NMR spectrum of the polymer obtained using Co1/MMAO [run $6\left(80{ }^{\circ} \mathrm{C}\right.$ ), Table 4] with an intense peak at $\delta 1.37$ corresponding to the methylene repeat unit. Furthermore, and similar to that seen with MAO, signals characteristic of a vinyl end group were observed in the ${ }^{1} \mathrm{H}$ NMR spectrum; the corresponding carbon signals were also evident in the ${ }^{13} \mathrm{C}$ NMR spectrum (Figure 16). A polyethylene sample obtained at $40{ }^{\circ} \mathrm{C}$ (run 2, Table 4), was also characterized by high temperature ${ }^{1} \mathrm{H}$ NMR spectroscopy (Figure S5). Once again a comparison of these two NMR spectra reveals that increasing the temperature raised the content of vinyl-end groups in line with greater $\beta-\mathrm{H}$ elimination to metal or to monomer.

To allow a comparison of the performance characteristics of $\mathbf{F}(\mathrm{Co1}-\mathrm{Co6})$ with previously reported binuclear cobalt

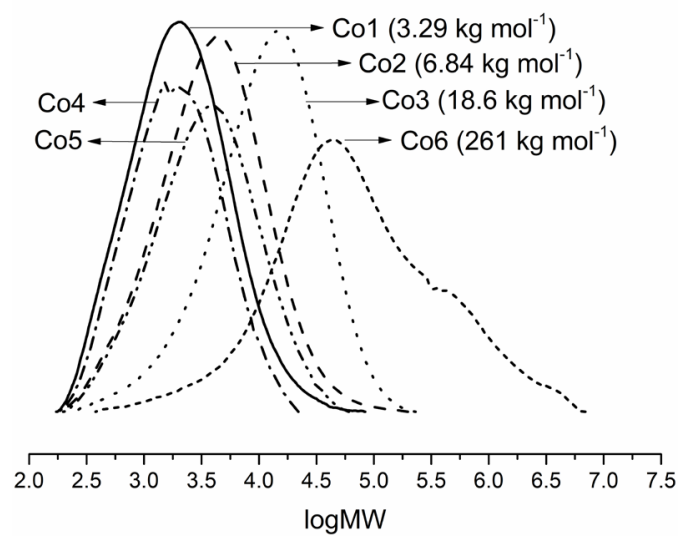


Figure 15 GPC traces of the polymer samples obtained using Co1 -

Co6/MMAO (runs 1-6, Table 5).

Table 5 Ethylene polymerization/oligomerization results obtained using Co1 - Co6/MMAOa

\begin{tabular}{|c|c|c|c|c|c|c|c|c|c|c|c|c|}
\hline \multirow[b]{2}{*}{ Run } & \multirow[b]{2}{*}{ Precat. } & \multirow[b]{2}{*}{$\begin{array}{l}\text { Overall } \\
\text { activity }^{b, c}\end{array}$} & \multicolumn{4}{|c|}{ Polymer } & \multicolumn{6}{|c|}{ Oligomerg } \\
\hline & & & $\begin{array}{l}\text { Activity } \\
(\text { polym })^{c}\end{array}$ & $M_{w}^{d, e}$ & $M_{\mathrm{w}} / M_{\mathrm{n}}^{\mathrm{e}}$ & $T_{\mathrm{m}}^{f}$ & $\begin{array}{l}\text { Activity } \\
\text { (olig) }^{c}\end{array}$ & $\sum \mathrm{C}_{4} / \Sigma \mathrm{C}^{\mathrm{h}}$ & $\sum \mathrm{C}_{6} / \Sigma \mathrm{C}^{\mathrm{h}}$ & $\sum \mathrm{C}_{8} / \Sigma \mathrm{C}^{\mathrm{h}}$ & $>\sum \mathrm{C}_{8} / \sum \mathrm{C}^{\mathrm{h}}$ & $\begin{array}{l}\alpha- \\
\mathrm{C} / \Sigma \mathrm{C}^{\mathrm{h}}\end{array}$ \\
\hline 1 & Co1 & 7.16 & 6.51 & 3.29 & 2.48 & 123.9 & 0.65 & 20.8 & 13.3 & 8.23 & 57.7 & $>99$ \\
\hline 2 & $\mathrm{Co2}$ & 6.24 & 5.71 & 6.84 & 3.02 & 128.1 & 0.53 & 42.2 & 16.9 & 9.30 & 31.6 & $>99$ \\
\hline 3 & Co3 & 6.92 & 6.67 & 18.6 & 3.18 & 131.5 & 0.25 & 42.9 & 18.2 & 7.84 & 31.1 & $>99$ \\
\hline 4 & Co4 & 8.32 & 6.51 & 2.78 & 2.12 & 125.2 & 1.81 & 49.7 & 22.4 & 7.94 & 20.0 & $>99$ \\
\hline 5 & Co5 & 5.80 & 4.53 & 5.56 & 2.63 & 127.8 & 1.27 & 54.4 & 22.7 & 11.1 & 11.8 & $>99$ \\
\hline 6 & Co6 & 2.44 & 2.44 & 261 & 13.2 & 135.0 & \multicolumn{6}{|l|}{ Trace } \\
\hline \multicolumn{13}{|c|}{${ }^{a}$ Conditions: $1.5 \mu \mathrm{mol}$ of cobalt precatalyst; 10 atm $\mathrm{C}_{2} \mathrm{H}_{4} ; 100 \mathrm{~mL}$ of toluene, $80^{\circ} \mathrm{C}$ run temperature, $\mathrm{Al}: \mathrm{Co}$ ratio $=1000}$. \\
\hline \multicolumn{13}{|c|}{ b Overall activity = activity (polym) + activity (olig). } \\
\hline \multicolumn{13}{|c|}{${ }^{c}$ In units of $\times 10^{6} \mathrm{~g}(\mathrm{PE}) \cdot \mathrm{mol}^{-1}(\mathrm{Co}) \cdot \mathrm{h}^{-1}$} \\
\hline \multicolumn{13}{|c|}{ d In units of kg mol-1. } \\
\hline \multicolumn{13}{|c|}{ e Determined by GPC. } \\
\hline \multicolumn{13}{|c|}{${ }^{f}$ Determined by DSC; in units of ${ }^{\circ} \mathrm{C}$. } \\
\hline \multicolumn{13}{|c|}{ g Determined by GC. } \\
\hline \multicolumn{13}{|c|}{${ }^{\mathrm{h}} \sum \mathrm{C}_{4}, \sum \mathrm{C}_{6}, \sum \mathrm{C}_{8}$, and $\sum \mathrm{C}$ denote the total amounts of butene, hexene, octene and oligomers in mol\%, respectively. } \\
\hline
\end{tabular}

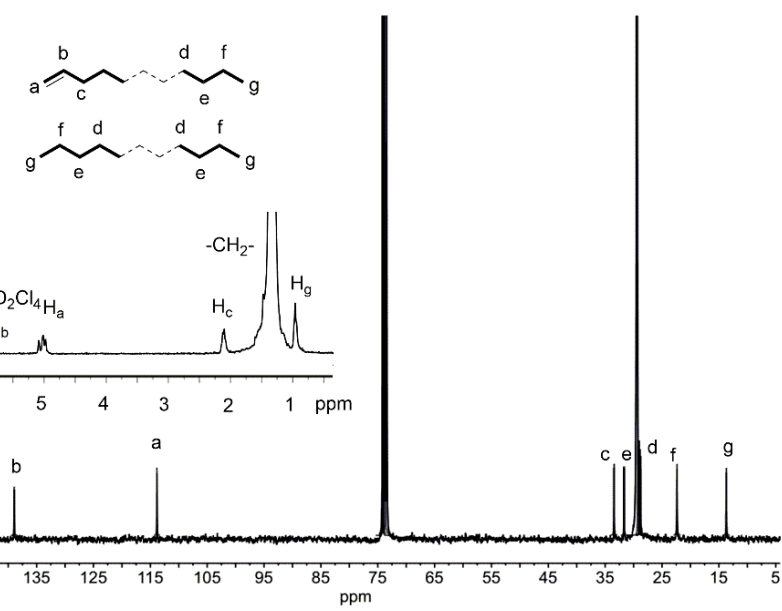

Figure $16{ }^{13} \mathrm{C}$ NMR spectrum of the polyethylene obtained in run 6 (Table 4), using Co1/MMAO ( $\delta \mathrm{C} 73.8$, tetrachloroethane- $d_{2}$ ); an insert showing the ${ }^{1} \mathrm{H}$ NMR spectrum is also given

complexes, Chart 2 collects together data obtained for some structurally related dicobalt precatalysts $(B-E)$ that have been screened under comparable conditions by employing MAO or MMAO as co-catalyst. $4,5 a, 10 b, 11 a$ In the current case, $\mathbf{F}$ can convert ethylene to oligomer and polymer with different temperatures affecting the relative ratios. At lower temperature, the product was mainly oligomer and showed higher catalytic activity as well as a higher selectivity for $\alpha$ olefins than in B. ${ }^{4}$ Although $\mathbf{C}$ displayed a higher optimal temperature for ethylene oligomerization than $\mathbf{F}$, the activity was lower than observed for F $\left(2.46\right.$ vs. $5.53 \times 10^{5} \mathrm{~g} \cdot \mathrm{mol}^{-}$ $\left.{ }^{1}(\mathrm{Co}) \cdot \mathrm{h}^{-1} \mathrm{~atm}^{-1}\right) .{ }^{5 a}$ In terms of polymerization, $\mathbf{F}$ displayed its highest activity at $70{ }^{\circ} \mathrm{C}(\mathrm{MAO})$ and $80^{\circ} \mathrm{C}$ (MMAO), suggesting that the cobalt complexes developed in this work possessed better thermal stability in terms of chain propagation when put alongside $\mathbf{C},{ }^{5 a} \mathbf{D}^{10 b}$ and E. ${ }^{11 a}$ It is noteworthy that when compared to $\mathbf{C}$, the higher polymerization activity of $\mathbf{F}$ can, in part, be attributed to the higher ethylene pressure employed in this study. ${ }^{1 b, 16}$ In addition when compared with $\mathbf{D}$, both the activity and molecular weight of the polymer obtained using $\mathbf{F}$ increased. Even though $\mathbf{E}$ showed comparable activity to $\mathbf{F}$, lower molecular weight polymer was a feature of this polymerization. To the best of our knowledge, $\mathbf{F}$ are the first examples of binuclear cobalt precatalysts that are capable of displaying such a broad range of molecular weights (e.g. 5.4 to $247 \times 10^{3} \mathrm{~g} \cdot \mathrm{mol}^{-1}$ with MAO as co-catalyst) that can be promoted through steric modulation of the $\mathrm{N}$-aryl substituents. 
<smiles></smiles>

oligomer

optimal temp. $\left({ }^{\circ} \mathrm{C}\right) \mid 25$

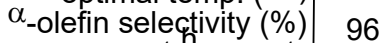
\begin{tabular}{l|l} 
activity $\left(\mathrm{g} \mathrm{mol}^{-1} \mathrm{~h}_{-1} \mathrm{~atm}^{-1}\right)$ & $8.50 \times 10^{5}$
\end{tabular}

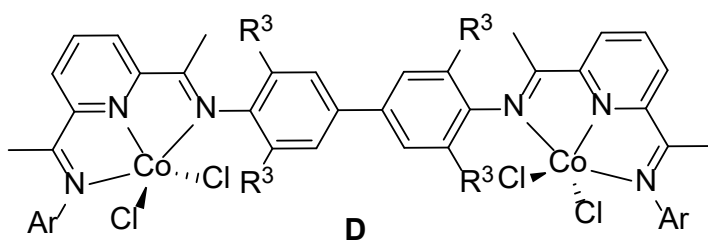

MAO

optimal temp. (o polymer \begin{tabular}{r|l|l}
$M\left(\mathrm{~g} \mathrm{~mol}_{-1}^{\mathrm{C}}\right)$ & $\begin{array}{l}50 \\
1.8-120 \times 10^{3}\end{array}$ & $\begin{array}{l}40 \\
1.4-2.0 \times 10^{3} \\
\operatorname{activity}\left(\mathrm{g} \mathrm{mol}_{-1}^{\mathrm{w}} \mathrm{h}_{-1} \mathrm{~atm}^{-1}\right)\end{array}$ \\
$7.7 \times 10^{5}$ & $6.0 \times 10^{5}$
\end{tabular}

MMAO

polymer

$6.0 \times 10^{5}$

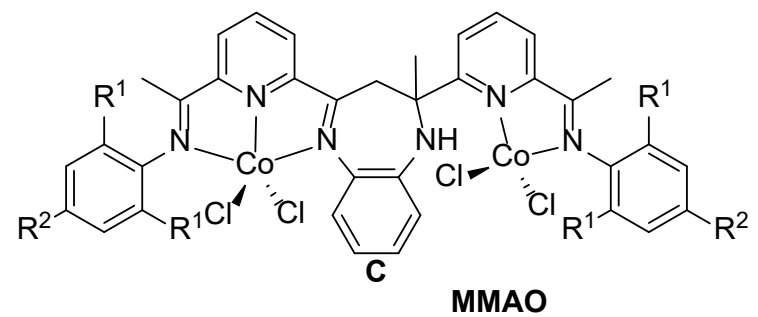

MMAO

$\left.\alpha \quad{ }^{\circ} \mathrm{C}\right) 60$

-olefin selectivity (\%) $>99$

activity $\left(\mathrm{g} \mathrm{mol}^{-1} \mathrm{~h}_{-1} \mathrm{~atm}^{-1}\right) \mid 2.46 \times 10^{5} \quad 7.37 \times 10^{5}$

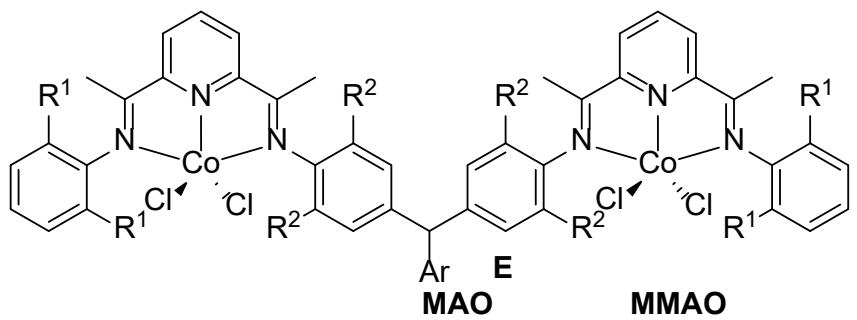

\begin{tabular}{r|l|l} 
optimal temp. (o & polymer & polymer \\
$M\left(\mathrm{~g} \mathrm{~mol}_{-1}^{\mathrm{C}}\right)$ & 50 & 50 \\
activity $\left(\mathrm{g} \mathrm{mol}_{-1}^{\mathrm{w}} \mathrm{h}_{-1} \mathrm{~atm}^{-1}\right)$ & $2.3-11.0 \times 10^{3}$ & $1.2-1.8 \times 10^{3}$ \\
$8.89 \times 10^{5}$ & $6.19 \times 10^{5}$
\end{tabular}
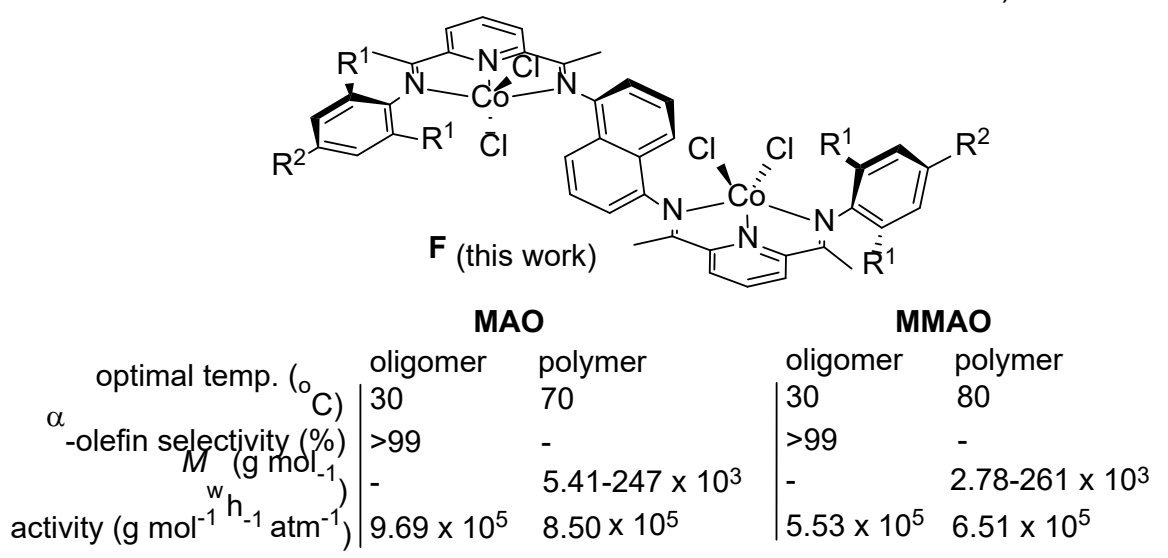

Chart 2 Comparative data for previously reported binuclear precatalysts B - E with F; all data obtained under similar conditions using MAO or MMAO as the co-catalyst.

\section{Conclusions}

Six types of bimetallic 1,5-naphthyl-linked bis(imino)pyridinecobalt(II) chloride complex, Co1 - Co6, have been successfully synthesized from bis(tridentate) L1 - L6 in reasonable yield; the molecular structures of $\mathrm{Co} 3$ and $\mathrm{Co} 4$ show the $(N, N, N) \mathrm{CoCl}_{2}$ units to adopt mutually anti-configurations. On activation with either MMAO or MAO, all six complexes were capable of displaying high activities for both polymerization and oligomerization with the relative proportion of the corresponding products dependent on the run temperature and to some extent the steric properties of the precatalyst. Notably, the formation of oligomeric products predominates at lower temperature while at higher temperature polymeric products are favored. Furthermore, all catalysts generated strictly linear polyethylene (all $T_{\mathrm{m}}$ values $>120^{\circ} \mathrm{C}$ ) with varying degrees of vinyl-end groups as well as oligomers with broad distributions that could be affected by temperature. In addition, the MAO-promoted polymerizations were more productive than their MMAO counterparts for either polymerization or oligomerization. In terms of polymer molecular weight, the values of $M_{\mathrm{w}}$ significantly increased $\left(4.52-246.7 \mathrm{~kg} \mathrm{~mol}^{-1}\right)$ with increasing steric hindrance of the ortho- $\mathrm{R}^{1}$ substituents. 


\section{Experimental}

General Considerations: All manipulations involving air- and moisture-sensitive compounds were carried out under a nitrogen atmosphere using standard Schlenk techniques. Toluene was refluxed over sodium and distilled under nitrogen prior to use. Methylaluminoxane (MAO, $1.46 \mathrm{M}$ solution in toluene) and modified methylaluminoxane (MMAO, $2.00 \mathrm{M}$ in n-heptane) were purchased from Akzo Nobel Corp. High-purity ethylene was purchased from Beijing Yansan Petrochemical Co. and used as received. Other reagents were purchased from Aldrich, Acros or local suppliers. The NMR spectra of L1 - L6 were recorded on a Bruker DMX 300 or $400 \mathrm{MHz}$ instrument at ambient temperature using TMS as an internal standard, while NMR spectra of the polyethylenes were recorded on a Bruker DMX $300 \mathrm{MHz}$ instrument at $100{ }^{\circ} \mathrm{C}$ in 1,1,2,2tetrachloroethane- $d_{2}$ with TMS as an internal standard. IR spectra were recorded on a Perkin-Elmer System 2000 FT-IR spectrometer. Elemental analysis was carried out using a Flash EA 1112 micro-analyzer. Molecular weight and molecular weight distributions $\left(M_{\mathrm{w}} / M_{\mathrm{n}}\right)$ of the polyethylenes were obtained using a PL-GPC220 instrument at $150{ }^{\circ} \mathrm{C}$ using 1,2,4trichlorobenzene as the solvent. The melting temperatures of the polyethylenes were measured from the fourth scanning run on a Perkin-Elmer TA-Q2000 differential scanning calorimeter (DSC) under a nitrogen atmosphere. In the procedure, a sample of about $5.0 \mathrm{mg}$ was heated to $160{ }^{\circ} \mathrm{C}$ at a rate of $20{ }^{\circ} \mathrm{C} \mathrm{min}-1$ and maintained for $2 \mathrm{~min}$ at $160{ }^{\circ} \mathrm{C}$ to remove the thermal history and then cooled at a rate of $20^{\circ} \mathrm{C}$ $\min ^{-1}$ to $20{ }^{\circ} \mathrm{C}$. Compounds 2-(CMeO)-6- $\left\{\mathrm{CMe}=\mathrm{N}\left(2,6-\mathrm{R}^{1}{ }_{2}-4-\mathrm{R}^{2}\right.\right.$ $\left.\left.\mathrm{C}_{6} \mathrm{H}_{2}\right)\right\} \mathrm{C}_{5} \mathrm{H}_{3} \mathrm{~N}\left(\mathrm{R}^{1}=\mathrm{Me}, \mathrm{R}^{2}=\mathrm{H} ; \mathrm{R}^{1}=\mathrm{Et}, \mathrm{R}^{2}=\mathrm{H} ; \mathrm{R}^{1}={ }^{i} \mathrm{Pr}, \mathrm{R}^{2}=\mathrm{H} ; \mathrm{R}^{1}\right.$ $\left.=R^{2}=M e ; R^{1}=E t, R^{2}=M e ; R^{1}=C H P h_{2}, R^{2}=M e\right)$, were prepared according to literature procedures. ${ }^{13}$

Synthesis of $\left[1,5-\left\{2-(C M e=N)-6-\left(C M e=N\left(2,6-R^{1}{ }_{2}-4-R^{2}-\right.\right.\right.\right.$

$\left.\left.\left.\mathrm{C}_{6} \mathrm{H}_{2}\right)\right) \mathrm{C}_{5} \mathrm{H}_{3} \mathrm{~N}\right\}_{2}\left(\mu-\mathrm{C}_{10} \mathrm{H}_{6}\right)(\mathrm{L} 1-\mathrm{L} 6)$

(a) $\mathrm{R}^{1}=\mathrm{Me}, \mathrm{R}^{2}=\mathrm{H} \mathbf{L}$. A toluene solution $(150 \mathrm{~mL})$ containing 2-(CMeO)-6- $\left\{\mathrm{CMe}=\mathrm{N}\left(2,6-\mathrm{Me}_{2} \mathrm{C}_{6} \mathrm{H}_{3}\right)\right\} \mathrm{C}_{5} \mathrm{H}_{3} \mathrm{~N}$ (2.61 g, $\left.10 \mathrm{mmol}\right)$, 1,5-diaminonaphthalene $(0.63 \mathrm{~g}, 4.0 \mathrm{mmol})$ and a catalytic amount of $p$-toluenesulfonic acid ( $2 \mathrm{~mol} \%$ ) was stirred and heated to reflux for $20 \mathrm{~h}$ under a nitrogen atmosphere. On cooling to room temperature, the solvent was removed by rotary evaporation. The minimum amount of dichloromethane was added to fully dissolve the residue before heptane $(50 \mathrm{~mL})$ was added to induce precipitation. The solid was removed by filtration and more heptane $(100 \mathrm{~mL})$ added to the filtrate. After about $5 \mathrm{~h}$, the resulting precipitate was filtered affording L1 as a yellow powder (0.90 g, 34\%). ${ }^{1} \mathrm{H}$ NMR $\left(400 \mathrm{MHz}, \mathrm{CDCl}_{3}\right)$ : $\delta 8.69(\mathrm{~d}, J=8.0 \mathrm{~Hz}, 2 \mathrm{H}, \mathrm{Py}-H), 8.52(\mathrm{~d}, J=8.0 \mathrm{~Hz}, 2 \mathrm{H}, \mathrm{Py}-H)$, $7.96(\mathrm{t}, J=8.0 \mathrm{~Hz}, 2 \mathrm{H}, \mathrm{Py}-H), 7.60(\mathrm{~d}, J=8.0 \mathrm{~Hz}, 2 \mathrm{H}, \mathrm{Ar}-H), 7.43$ $(\mathrm{t}, J=7.6 \mathrm{~Hz}, 2 \mathrm{H}, \operatorname{Ar}-H), 7.24(\mathrm{~d}, J=2.4 \mathrm{~Hz}, 4 \mathrm{H}, \operatorname{Ar}-H), 6.95(\mathrm{t}, J=$ $7.2 \mathrm{~Hz}, 2 \mathrm{H}, \operatorname{Ar}-H), 6.87(\mathrm{~d}, J=7.2 \mathrm{~Hz}, 2 \mathrm{H}, \operatorname{Ar}-H), 2.45(\mathrm{~s}, 6 \mathrm{H}$, $\left.\mathrm{N}=\mathrm{CCH}_{3}\right), 2.27\left(\mathrm{~s}, 6 \mathrm{H}, \mathrm{N}=\mathrm{CCH}_{3}\right), 2.08\left(\mathrm{~s}, 12 \mathrm{H},-\mathrm{CH}_{3}\right) .{ }^{13} \mathrm{C} \mathrm{NMR}$ $\left(100 \mathrm{MHz}, \mathrm{CDCl}_{3}\right): \delta 168.4,167.3,155.6,155.4,148.9,147.8$, $137.1,128.1,126.7,125.7,125.6,125.4,124.7,123.3,123.2$, $122.7,122.5,119.4,116.6,114.6,113.9,111.7,110.0,18.1$, 16.7, 16.6. FT-IR $\left(\mathrm{KBr}, \mathrm{cm}^{-1}\right): 2960(\mathrm{w}), 2918(\mathrm{w}), 2861(\mathrm{w})$, $1639(\mathrm{~s}), 1573(\mathrm{~m}), 1499(\mathrm{w}), 1463(\mathrm{~m}), 1425(\mathrm{~m}), 1402(\mathrm{w})$,
1360 (s), 1321 (w), 1245 (w), 1204 (s), 1117 (m), $1096(\mathrm{~m})$, $1075(\mathrm{~m}), 988(\mathrm{w}), 905(\mathrm{~m}), 815(\mathrm{~m}), 764(\mathrm{~s}), 739(\mathrm{~s}), 688(\mathrm{~m})$. Anal. Calcd. for $\mathrm{C}_{44} \mathrm{H}_{42} \mathrm{~N}_{6}$ (738.44): C, 80.70; $\mathrm{H}, 6.46 ; \mathrm{N}, 12.83$. Found: $\mathrm{C}, 80.50 ; \mathrm{H}, 6.80 ; \mathrm{N}, 12.47 \%$.

(b) $R^{1}=E t, R^{2}=H$ L2. Using the same procedure and work-up as described for the synthesis of $\mathbf{L 1}, \mathbf{L 2}$ was isolated as a yellow solid (0.95 g, 33\%). ${ }^{1} \mathrm{H}$ NMR $\left(400 \mathrm{MHz}, \mathrm{CDCl}_{3}\right): \delta 8.59(\mathrm{~d}, J=8.0$ $\mathrm{Hz}, 2 \mathrm{H}, \mathrm{Py}-H) .8 .21$ (d, $J=8.0 \mathrm{~Hz}, 2 \mathrm{H}, \mathrm{Py}-H), 7.97(\mathrm{t}, J=8.0 \mathrm{~Hz}$, $2 \mathrm{H}, \mathrm{Py}-H), 7.60$ (d, J = 8.4 Hz, 2H, Ar-H), $7.43(\mathrm{t}, J=7.6 \mathrm{~Hz}, 2 \mathrm{H}$, $\operatorname{Ar}-H), 7.13(\mathrm{~d}, J=7.6 \mathrm{~Hz}, 4 \mathrm{H}, \operatorname{Ar}-H), 7.04(\mathrm{t}, J=7.6 \mathrm{~Hz}, 2 \mathrm{H}, \mathrm{Ar}-$ $H), 6.87(\mathrm{~d}, J=6.8 \mathrm{~Hz}, 2 \mathrm{H}, \mathrm{Ar}-\mathrm{H}), 2.48-2.34\left(\mathrm{~m}, 14 \mathrm{H}, \mathrm{N}=\mathrm{CCH}_{3}\right.$ and $\left.-\mathrm{CH}_{2} \mathrm{Me}\right), 2.28\left(\mathrm{~s}, 6 \mathrm{H}, \mathrm{N}=\mathrm{CCH}_{3}\right), 1.17(\mathrm{t}, J=7.6 \mathrm{~Hz}, 12 \mathrm{H}$, $\left.\mathrm{CH}_{3}\right) .{ }^{13} \mathrm{C} \mathrm{NMR}\left(100 \mathrm{MHz}, \mathrm{CDCl}_{3}\right): \delta 168.5,167.0,155.6,155.4$, 148.0, 147.9, 137.1, 126.7, 126.1, 125.6, 124.9, 123.5, 122.7, $122.5,119.4,113.9,25.7,24.8,17.0,16.7,16.6,13.9$. FT-IR $\left(\mathrm{KBr}, \mathrm{cm}^{-1}\right): 2964(\mathrm{~m}), 2929(\mathrm{w}), 2871(\mathrm{w}), 1636(\mathrm{~s}), 1573(\mathrm{~m})$, $1508(\mathrm{~m}), 1451(\mathrm{~m}), 1404(\mathrm{~m}), 1361(\mathrm{~s}), 1320(\mathrm{w}), 1295(\mathrm{w})$, $1238(\mathrm{~s}), 1198(\mathrm{~m}), 1116(\mathrm{~m}), 1075(\mathrm{~m}), 991(\mathrm{w}), 908(\mathrm{~m}), 873$ (w), $817(\mathrm{~m}), 768(\mathrm{~s}), 739(\mathrm{~m}), 691(\mathrm{~m})$. Anal. Calcd. for $\mathrm{C}_{48} \mathrm{H}_{50} \mathrm{~N}_{6}$ (710.41): C, 81.09; H, 7.09; N, 11.82. Found: C, 81.23; $\mathrm{H}, 8.10 ; \mathrm{N}, 11.55 \%$.

(c) $\mathrm{R}^{1}={ }^{i} \mathrm{Pr}, \mathrm{R}^{2}=\mathrm{H}$ L3. Using the same procedure and work-up as described for the synthesis of $\mathbf{L 1}, \mathbf{L} \mathbf{3}$ was isolated as a yellow solid (0.95 g, 31\%). ${ }^{1} \mathrm{H}$ NMR (400 MHz, $\left.\mathrm{CDCl}_{3}\right): \delta 8.60$ (d, $J=7.6$ $\mathrm{Hz}, 2 \mathrm{H}, \mathrm{Py}-H), 8.52$ (d, $J=8.0 \mathrm{~Hz}, 2 \mathrm{H}, \mathrm{Py}-H), 7.97(\mathrm{t}, J=7.6 \mathrm{~Hz}$, $2 \mathrm{H}, \mathrm{Py}-H), 7.61$ (d, J = 8.4 Hz, 2H, Ar-H), $7.44(\mathrm{t}, J=8.0 \mathrm{~Hz}, 2 \mathrm{H}$, $\operatorname{Ar}-H), 7.18(\mathrm{~d}, J=7.6 \mathrm{~Hz}, 4 \mathrm{H}, \mathrm{Ar}-H), 7.11(\mathrm{t}, J=8.0 \mathrm{~Hz}, 2 \mathrm{H}, \mathrm{Ar}-$ $H), 6.87(\mathrm{~d}, J=7.2 \mathrm{~Hz}, 2 \mathrm{H}, \mathrm{Ar}-\mathrm{H}), 2.83-2.77(\mathrm{~m}, 4 \mathrm{H},-\mathrm{CHMe})_{2}$, $2.45\left(\mathrm{~s}, 6 \mathrm{H}, \mathrm{N}=\mathrm{CCH}_{3}\right), 2.30\left(\mathrm{~s}, 6 \mathrm{H}, \mathrm{N}=\mathrm{CCH}_{3}\right), 1.18(\mathrm{~d}, J=6.8 \mathrm{~Hz}$, $\left.24 \mathrm{H},-\mathrm{CH}_{3}\right) .{ }^{13} \mathrm{C}$ NMR $\left(100 \mathrm{MHz}, \mathrm{CDCl}_{3}\right): \delta 168.5,167.1,155.6$, $155.4,147.9,146.6,137.5,137.1,135.9,135.8,129.2,128.4$, 126.7, 125.6, 123.8, 123.2, 122.7, 122.5, 119.4, 113.9, 53.5, 28.5, 23.4, 23.1, 17.3, 16.7. FT-IR (KBr, cm$\left.{ }^{-1}\right): 2962(\mathrm{~m}), 2923$ (w), $2866(\mathrm{w}), 1635(\mathrm{~s}), 1575(\mathrm{~m}), 1503(\mathrm{~m}), 1455(\mathrm{~m}), 1402$ $(\mathrm{m}), 1361(\mathrm{~s}), 1321(\mathrm{w}), 1241(\mathrm{~s}), 1195(\mathrm{~m}), 1120(\mathrm{~s}), 1077(\mathrm{w})$, $1038(w), 989(w), 935(w), 907(w), 825(m), 773(s), 732(m)$, 689 (m). Anal. Calcd. for $\mathrm{C}_{52} \mathrm{H}_{58} \mathrm{~N}_{6}$ (766.47): C, 81.42; H, 7.62; N, 10.96. Found: C, 81.50; H, 7.92; N, 10.57\%.

(d) $R^{1}=M e, R^{2}=$ Me L4. Using the same procedure and workup as described for the synthesis of $\mathbf{L 1}, \mathbf{L} \mathbf{4}$ was isolated as a yellow solid $(1.20 \mathrm{~g}, 44 \%) .{ }^{1} \mathrm{H}$ NMR $\left(400 \mathrm{MHz}, \mathrm{CDCl}_{3}\right): \delta 8.58(\mathrm{~d}$, $J=8.0 \mathrm{~Hz}, 2 \mathrm{H}, \mathrm{Py}-H), 8.51(\mathrm{~d}, J=7.6 \mathrm{~Hz}, 2 \mathrm{H}, \mathrm{Py}-H) .7 .95(\mathrm{t}, J=$ $8.0 \mathrm{~Hz}, 2 \mathrm{H}, \mathrm{Py}-\mathrm{H}), 7.60(\mathrm{~d}, J=8.4 \mathrm{~Hz}, 2 \mathrm{H}, \mathrm{Ar}-H), 7.43(\mathrm{t}, J=8.0$ $\mathrm{Hz}, 2 \mathrm{H}, \mathrm{Ar}-H), 6.91(\mathrm{~s}, 4 \mathrm{H}, \mathrm{Ar}-H), 6.86(\mathrm{t}, J=7.2 \mathrm{~Hz}, 2 \mathrm{H}, \mathrm{Ar}-H)$, $2.44\left(\mathrm{~s}, 6 \mathrm{H}, \mathrm{N}=\mathrm{CCH}_{3}\right), 2.30\left(\mathrm{~s}, 6 \mathrm{H}, \mathrm{N}=\mathrm{CCH}_{3}\right), 2.26\left(\mathrm{~s}, 6 \mathrm{H},-\mathrm{CH}_{3}\right)$, $2.04\left(\mathrm{~s}, 12 \mathrm{H},-\mathrm{CH}_{3}\right) .{ }^{13} \mathrm{C} \mathrm{NMR}\left(100 \mathrm{MHz}, \mathrm{CDCl}_{3}\right): \delta 168.5,167.5$, $155.5,146.4,142.8,137.0,132.4,128.7,126.7,125.6,124.6$, $122.6,122.5,119.4,113.9,111.7,110.0,32.0,29.2,22.8,20.9$, 18.0, 16.7, 16.6, 14.2. FT-IR (KBr, cm$\left.{ }^{-1}\right): 2956(w), 2921(w)$, $2863(w), 1637(\mathrm{~s}), 1574(\mathrm{~m}), 1502(\mathrm{w}), 1452(\mathrm{~m}), 1401(\mathrm{~m})$, $1362(\mathrm{~s}), 1321(\mathrm{w}), 1243(\mathrm{~s}), 1213(\mathrm{~m}), 1150(\mathrm{w}), 1119(\mathrm{~s}), 1078$ $(w), 1037(w), 987(w), 903(w), 849(w), 823(m), 780(s), 742$ (m), $686(\mathrm{~m})$. Anal. Calcd. for $\mathrm{C}_{46} \mathrm{H}_{46} \mathrm{~N}_{6}$ (682.38): C, 80.90; $\mathrm{H}$, $6.79 ; \mathrm{N}, 12.31$. Found: $\mathrm{C}, 80.88 ; \mathrm{H}, 6.82 ; \mathrm{N}, 12.30 \%$.

(e) $\mathrm{R}^{1}=\mathrm{Et}, \mathrm{R}^{2}=\mathrm{Me} \mathbf{L 5}$. Using the same procedure and work-up as described for the synthesis of L1, L5 was isolated as a yellow solid (1.20 g, 41\%). ${ }^{1} \mathrm{H}$ NMR (400 MHz, $\mathrm{CDCl}_{3}$ ): $\delta 8.58$ (d, $J=8.0$ 
$\mathrm{Hz}, 2 \mathrm{H}, \mathrm{Py}-H), 8.50$ (d, $J=8.0 \mathrm{~Hz}, 2 \mathrm{H}, \mathrm{Py}-H), 7.95(\mathrm{t}, J=8.0 \mathrm{~Hz}$, $2 \mathrm{H}, \mathrm{Py}-\mathrm{H}), 7.60(\mathrm{~d}, J=8.4 \mathrm{~Hz}, 2 \mathrm{H}, \mathrm{Ar}-H), 7.43(\mathrm{t}, J=8.0 \mathrm{~Hz}, 2 \mathrm{H}$ $\operatorname{Ar}-H), 6.95(\mathrm{~s}, 4 \mathrm{H}, \operatorname{Ar}-H), 6.87(\mathrm{t}, J=7.2 \mathrm{~Hz}, 2 \mathrm{H}, \operatorname{Ar}-H), 2.44(\mathrm{~s}$, $\left.6 \mathrm{H}, \mathrm{N}=\mathrm{CCH}_{3}\right), 2.43-2.35\left(\mathrm{~m}, 14 \mathrm{H},-\mathrm{CH}_{2} \mathrm{Me}\right.$ and $\left.-\mathrm{CH}_{3}\right), 2.28(\mathrm{~s}, 6 \mathrm{H}$, $\left.\mathrm{N}=\mathrm{CCH}_{3}\right), 1.14\left(\mathrm{~s}, 12 \mathrm{H},-\mathrm{CH}_{3}\right) \cdot{ }^{13} \mathrm{C} \mathrm{NMR}\left(100 \mathrm{MHz}, \mathrm{CDCl}_{3}\right): \delta$ $168.5,167.2,155.5,146.9,145.4,142.8,137.1,132.6,131.2$, $126.9,126.7,125.6,125.4,124.9,124.6,122.6,122.4,119.4$, 114.6, 113.9, 113.5, 111.7, 110.3, 110.0, 24.8, 21.1, 16.9, 16.7 14.0. FT-IR (KBr, cm$\left.{ }^{-1}\right): 2963(\mathrm{~m}), 2926(\mathrm{w}), 2867(\mathrm{w}), 1636(\mathrm{~s})$, $1573(\mathrm{~m}), 1502(\mathrm{~m}), 1457(\mathrm{~s}), 1420(\mathrm{~m}), 1363(\mathrm{~s}), 1321(\mathrm{w})$, $1298(\mathrm{w}), 1242(\mathrm{~s}), 1208(\mathrm{~m}), 1148(\mathrm{w}), 1118(\mathrm{~s}), 1077(\mathrm{~m}), 988$ $(w), 904(w), 855(w), 824(s), 779(s), 743(m), 687(m)$. Anal. Calcd. for $\mathrm{C}_{50} \mathrm{H}_{54} \mathrm{~N}_{6}$ (738.44): C, 81.26; $\mathrm{H}, 7.17 ; \mathrm{N}, 11.37$. Found: C, 81.50; H, 7.10; N, 11.27\%.

(e) $\mathrm{R}^{1}=\mathrm{CHPh}_{2}, \mathrm{R}^{2}=\mathrm{Me}$ L6. Using the same procedure and work-up as described for the synthesis of L1, L6 was isolated as a yellow solid $(0.94 \mathrm{~g}, 18 \%) .{ }^{1} \mathrm{H}$ NMR $\left(400 \mathrm{MHz}, \mathrm{CDCl}_{3}\right): \delta 8.53$ (d, $J=6.8 \mathrm{~Hz}, 2 \mathrm{H}, \mathrm{Py}-H), 8.12(\mathrm{~d}, J=6.8 \mathrm{~Hz}, 2 \mathrm{H}, \mathrm{Py}-H), 7.96(\mathrm{~s}$, $2 \mathrm{H}, \mathrm{Py}-H), 7.61(\mathrm{~d}, J=8.0 \mathrm{~Hz}, 2 \mathrm{H}, \mathrm{Ar}-H), 7.44(\mathrm{~s}, 2 \mathrm{H}, \mathrm{Ar}-H), 7.25-$ $7.06(\mathrm{~m}, 40 \mathrm{H}, \mathrm{Ph}-H), 6.86(\mathrm{t}, J=5.6 \mathrm{~Hz}, 2 \mathrm{H}, \operatorname{Ar}-H), 6.70(\mathrm{~s}, 4 \mathrm{H}$, Ar- $H$ ), 5.32 (s, 4H, -CHPh). 2.31 (s, 6H, N=CCH $), 2.19(\mathrm{~s}, 6 \mathrm{H}$, $\left.\mathrm{N}=\mathrm{CCH}_{3}\right), 1.12\left(\mathrm{~s}, 6 \mathrm{H},-\mathrm{CH}_{3}\right) \cdot{ }^{13} \mathrm{C} \mathrm{NMR}\left(100 \mathrm{MHz}, \mathrm{CDCl}_{3}\right): \delta$ $170.1,168.6,155.4,155.3,147.9,146.2,143.9,142.8,136.8$, $132.4,131.8,130.1,129.6,128.8,128.4,128.2,126.7,126.3$, 126.2, 125.6, 122.6, 122.4, 119.4, 114.0, 52.3, 27.1, 21.5, 17.0, 16.7. FT-IR (KBr, cm$\left.{ }^{-1}\right): 2960(\mathrm{~m}), 2923(\mathrm{w}), 2871(\mathrm{w}), 1639(\mathrm{~s})$, $1575(\mathrm{~m}), 1496(\mathrm{~m}), 1452(\mathrm{~m}), 1402(\mathrm{w}), 1362(\mathrm{~s}), 1321(\mathrm{w})$, $1241(\mathrm{~s}), 1200(\mathrm{~m}), 1078(w), 1036(w), 990(w), 909(w), 855$ $(\mathrm{m}), 821(\mathrm{~m}), 779(\mathrm{~s}), 741(\mathrm{~m}), 699(\mathrm{~m})$. Anal. Calcd. for $\mathrm{C}_{94} \mathrm{H}_{78} \mathrm{~N}_{6}$ (1290.63): $\mathrm{C}, 87.41 ; \mathrm{H}, 6.09 ; \mathrm{N}, 6.51$. Found: $\mathrm{C}, 87.52$; H, 5.99; N, 6.41\%.

\section{Preparation of [1,5- $\left\{2-(\mathrm{CMe}=\mathrm{N})-6-\left(\mathrm{CMe}=\mathrm{N}\left(2,6-\mathrm{R}^{1}{ }_{2}-4-\mathrm{R}^{2}-\right.\right.\right.$} $\left.\left.\left.\left.\mathrm{C}_{6} \mathrm{H}_{2}\right)\right) \mathrm{C}_{5} \mathrm{H}_{3} \mathrm{~N}\right\}_{2}\left(\mu-\mathrm{C}_{10} \mathrm{H}_{6}\right)\right] \mathrm{CO}_{2} \mathrm{Cl}_{4}(\mathrm{Co} 1-\mathrm{Co} 6)$

(a) $R^{1}=M e, R^{2}=H$ Co1. A Schlenk flask was evacuated and back-filled with nitrogen three times before L1 $(0.20 \mathrm{~g}, 0.30$ $\mathrm{mmol}), \mathrm{CoCl}_{2}(0.078 \mathrm{~g}, 0.60 \mathrm{mmol})$ and freshly distilled methanol $(10 \mathrm{~mL})$ were introduced. The reaction mixture was stirred at room temperature overnight affording a precipitate. This precipitate was filtered, washed with diethyl ether and dried under reduced pressure to give Co1 as green powder (0.23 g, 84\%). FT-IR (KBr, cm-1): $2912(\mathrm{w}), 1625$ (m), 1587 (s), $1505(w), 1496(m), 1470(m), 1429(w), 1400(m), 1374(m)$, $1321(w), 1259$ (s), $1213(\mathrm{~s}), 1103(\mathrm{w}), 1027(\mathrm{~m}), 991(\mathrm{w}), 910$ (w), $855(\mathrm{~m}), 822$ (s), 779 (s), 734 (s). Anal. Calcd. for $\mathrm{C}_{44} \mathrm{H}_{42} \mathrm{Cl}_{4} \mathrm{Co}_{2} \mathrm{~N}_{6} \cdot \mathrm{H}_{2} \mathrm{O}$ (930.10): C, 56.67; $\mathrm{H}, 4.76 ; \mathrm{N}, 9.01$. Found: C, 56.68; H, 4.73; N, 9.10\%.

(b) $\mathrm{R}^{1}=\mathrm{Et}, \mathrm{R}^{2}=\mathrm{H}$ Co2. Using the same procedure and molar ratios as described for the synthesis of Co1, Co2 was isolated as yellow powder $(0.24 \mathrm{~g}, 82 \%)$. FT-IR $\left(\mathrm{KBr}, \mathrm{cm}^{-1}\right): 2963(\mathrm{w})$, $2939(\mathrm{w}), 1625(\mathrm{~m}), 1587(\mathrm{~s}), 1509(\mathrm{w}), 1465(\mathrm{~m}), 1403(\mathrm{~m})$, $1372(\mathrm{~m}), 1323(\mathrm{w}), 1261(\mathrm{~s}), 1209(\mathrm{~m}), 1106(\mathrm{w}), 1027(\mathrm{w}), 910$ (w), 778 (s), 744 (s). Anal. Calcd. for $\mathrm{C}_{48} \mathrm{H}_{50} \mathrm{Cl}_{4} \mathrm{Co}_{2} \mathrm{~N}_{6} \cdot 2 \mathrm{H}_{2} \mathrm{O}$ (1004.17): C, 57.27; H, 5.41; N, 8.35. Found: C, 57.38; H, 5.12; $\mathrm{N}, 8.44 \%$.

(c) $\mathrm{R}^{1}={ }^{i} \mathrm{Pr}, \mathrm{R}^{2}=\mathrm{H}$ Co3. Using the same procedure and molar ratios as described for the synthesis of Co1, Co3 was obtained as yellow powder $(0.23 \mathrm{~g}, 75 \%)$. FT-IR $\left(\mathrm{KBr}, \mathrm{cm}^{-1}\right)$ : $2963(\mathrm{w})$, $1624(\mathrm{w}), 1586(\mathrm{~s}), 1507(\mathrm{w}), 1465(\mathrm{~m}), 1402(\mathrm{~m}), 1373(\mathrm{~m})$, $1323(w), 1260(\mathrm{~s}), 1209(\mathrm{~m}), 1105(\mathrm{w}), 1026(\mathrm{w}), 912(\mathrm{w}), 825$ (s), 780 (s). Anal. Calcd. for $\mathrm{C}_{52} \mathrm{H}_{58} \mathrm{Cl}_{4} \mathrm{CO}_{2} \mathrm{~N}_{6} \cdot \mathrm{H}_{2} \mathrm{O}$ (1042.22): C, 59.78; $\mathrm{H}, 5.79 ; \mathrm{N}, 8.04$. Found: $\mathrm{C}, 59.92 ; \mathrm{H}, 5.80 ; \mathrm{N}, 7.77 \%$.

(d) $R^{1}=\mathrm{Me}, \mathrm{R}^{2}=\mathrm{Me}$ Co4. Using the same procedure and molar ratios as described for the synthesis of Co1, Co4 was obtained as green powder $(0.23 \mathrm{~g}, 81 \%)$. FT-IR $\left(\mathrm{KBr}, \mathrm{cm}^{-1}\right): 2908(\mathrm{w})$, $1625(\mathrm{~m}), 1588$ (s), 1505 (w), 1472 (w), $1429(\mathrm{w}), 1374(\mathrm{~m})$, 1323 (w), 1260 (s), 1219 (s), 1163 (w), 1107 (w), 1026 (m), 908 $(w), 856(w), 822(s), 779$ (s), 748 (m). Anal. Calcd. for $\mathrm{C}_{46} \mathrm{H}_{46} \mathrm{Cl}_{4} \mathrm{Co}_{2} \mathrm{~N}_{6} \cdot \mathrm{H}_{2} \mathrm{O}$ (958.13): C, 57.52; $\mathrm{H}, 5.04 ; \mathrm{N}, 8.73$. Found: C, 57.70; $\mathrm{H}, 4.90 ; \mathrm{N}, 8.49 \%$.

(e) $\mathrm{R}^{1}=\mathrm{Et}, \mathrm{R}^{2}=\mathrm{Me}$ Co5. Using the same procedure and molar ratios as described for the synthesis of Co1, Co5 was obtained as green powder $(0.21 \mathrm{~g}, 70 \%)$. FT-IR $\left(\mathrm{KBr}, \mathrm{cm}^{-1}\right): 2968(\mathrm{~m})$, $2930(w), 2878(w), 1624(m), 1586(s), 1505(w), 1462(m)$, $1428(\mathrm{~m}), 1399(\mathrm{~m}), 1372(\mathrm{~s}), 1326(\mathrm{w}), 1260(\mathrm{~s}), 1215(\mathrm{~s}), 1162$ (w), $1107(w), 1026(\mathrm{~m}), 907(\mathrm{w}), 862(\mathrm{w}), 822(\mathrm{~s}), 779(\mathrm{~s}), 747$ (m). Anal. Calcd. for $\mathrm{C}_{50} \mathrm{H}_{54} \mathrm{Cl}_{4} \mathrm{CO}_{2} \mathrm{~N}_{6} \cdot \mathrm{H}_{2} \mathrm{O}$ (1014.19): C, 59.07; $\mathrm{H}$, 5.55; N, 8.27. Found: C, 58.73; $\mathrm{H}, 5.42 ; \mathrm{N}, 8.03 \%$.

(f) $\mathrm{R}^{1}=\mathrm{CHPh}_{2}, \mathrm{R}^{2}=\mathrm{Me}$ Co6. Using the same procedure and molar ratios as described for the synthesis of Co1, Co6 was obtained as a yellow powder $(0.29 \mathrm{~g}, 62 \%)$. FT-IR $\left(\mathrm{KBr}, \mathrm{cm}^{-1}\right)$ : $2968(w), 2922(w), 2864(w), 1621(m), 1586(s), 1494(m)$, $1447(\mathrm{~m}), 1401(\mathrm{w}), 1371(\mathrm{~s}), 1323(\mathrm{w}), 1265$ (s), $1214(\mathrm{~s}), 1189$ (w), $1079(w), 1028(\mathrm{~m}), 914(\mathrm{w}), 774(\mathrm{~s}), 746(\mathrm{~m}), 703$ (s). Anal. Calcd. for $\mathrm{C}_{94} \mathrm{H}_{78} \mathrm{Cl}_{4} \mathrm{Co}_{2} \mathrm{~N}_{6} \cdot 2 \mathrm{H}_{2} \mathrm{O}$ (1584.39): C, 71.17; $\mathrm{H}, 5.21 ; \mathrm{N}$, 5.29. Found: C, 71.25; $\mathrm{H}, 5.07 ; \mathrm{N}, 5.06 \%$.

\section{Ethylene polymerization at 5 or 10 atm $\mathrm{C}_{2} \mathrm{H}_{4}$}

The polymerizations conducted at 5 or 10 atm $\mathrm{C}_{2} \mathrm{H}_{4}$ were carried out in a $250 \mathrm{~mL}$ stainless steel autoclave equipped with a mechanical stirrer and temperature controller. In addition, the reactor was equipped with a thermocouple to control the reaction temperature and any exotherm generated could be regulated by adjusting the water flow in the steel tube inside the autoclave. The autoclave was evacuated and refilled with nitrogen two times and then with ethylene once. The precatalyst was then dispersed in toluene by using ultrasonic shaking due to its poor solubility in toluene. When the required temperature was reached, the precatalyst $(1.5 \mu \mathrm{mol})$ in toluene $(25 \mathrm{~mL})$ was injected into the autoclave under an ethylene atmosphere (ca. $1 \mathrm{~atm})$. Any residual precatalyst was washed into the autoclave with toluene $(2 \times 25 \mathrm{~mL})$. The required amount of co-catalyst (MAO, MMAO) and additional solvent were added successively by syringe taking the total volume of toluene to $100 \mathrm{~mL}$. The autoclave was immediately pressurized with 5 or 10 atm $\mathrm{C}_{2} \mathrm{H}_{4}$ and the stirring commenced. After the required reaction time, the reactor was cooled with an ice/water bath and the excess ethylene slowly vented. To determine the composition and distribution of the oligomers obtained, a small amount of the cooled reaction solution was quickly collected, quenched with $5 \%$ aqueous hydrogen chloride and analyzed by gas chromatography (GC). The remaining reaction solution was then quenched with $10 \%$ hydrochloric acid in ethanol and the precipitated polymer 
collected, washed with ethanol and then dried under reduced pressure at $50{ }^{\circ} \mathrm{C}$ to constant weight and weighed.

\section{Ethylene polymerization at $1 \mathrm{~atm} \mathrm{C}_{2} \mathrm{H}_{4}$}

The polymerization at 1 atm $\mathrm{C}_{2} \mathrm{H}_{4}$ was carried out in a Schlenk tube. Under an ethylene atmosphere (ca. $1 \mathrm{~atm})$, Co1 (1.5 umol) was added followed by toluene $(30 \mathrm{~mL})$ and then the required amount of co-catalyst (MAO, MMAO) introduced by syringe. The resulting solution was stirred at the required temperature under $1 \mathrm{~atm} \mathrm{C}_{2} \mathrm{H}_{4}$. After $30 \mathrm{~min}$, the Schlenk tube was cooled with an ice/water bath and the ethylene pressure slowly vented. A small amount of the cooled reaction solution was quickly collected, quenched with $5 \%$ aqueous hydrogen chloride and then analyzed by GC. The remaining reaction solution was quenched with $10 \%$ hydrochloric acid in ethanol. The precipitated polymer was washed with ethanol, dried under reduced pressure at $40^{\circ} \mathrm{C}$ and then weighed.

\section{X-ray structure determination}

The single-crystal X-ray diffraction studies of L2, Co3 and Co5 were conducted on a Rigaku Sealed Tube CCD (Saturn 724+) diffractometer with graphite-monochromated Mo- $\mathrm{K}_{\alpha}$ radiation $(\lambda=0.71073 \AA)$ at $173(2) \mathrm{K}$; the cell parameters were obtained by global refinement of the positions of all collected reflections. Intensities were corrected for Lorentz and polarization effects and empirical absorption. The structures were solved by direct methods and refined by full-matrix leastsquares on $F^{2}$. All non-hydrogen atoms were refined anisotropically and all hydrogen atoms were placed in calculated positions. Structure solution was performed by using the SHELXT (Sheldrick, 2015) ${ }^{24 a}$ and and structure refinement was performed by using the SHELXL (Sheldrick, 2015).24b During the structural refinement, the disordered solvent was squeezed (Co3) with PLATON software. ${ }^{25}$ Crystal data and processing parameters for L2, Co3 and Co5 are summarized in Table 6.

Table 6 Crystal data and structure refinement details for L2, Co3 and Co5

\begin{tabular}{|c|c|c|c|}
\hline & $\mathbf{L 2}$ & $\mathrm{Co} 3 \cdot 2 \mathrm{Me}_{2} \mathrm{NCHO} \cdot 2 \mathrm{H}_{2} \mathrm{O}$ & $\mathrm{Co} 5 \cdot 2 \mathrm{Me}_{2} \mathrm{NCHO}$ \\
\hline Empirical formula & $\mathrm{C}_{48} \mathrm{H}_{50} \mathrm{~N}_{6}$ & $\mathrm{C}_{58} \mathrm{Cl}_{4} \mathrm{CO}_{2} \mathrm{H}_{76} \mathrm{~N}_{8} \mathrm{O}_{4}$ & $\mathrm{C}_{56} \mathrm{Cl}_{4} \mathrm{Co}_{2} \mathrm{H}_{68} \mathrm{~N}_{8} \mathrm{O}_{2}$ \\
\hline Formula weight & 710.94 & 1208.92 & 1144.84 \\
\hline Temperature/K & 173.15 & $173(2)$ & 173.15 \\
\hline Wavelength/Å & 0.71073 & 0.71073 & 0.71073 \\
\hline Crystal system & triclinic & monoclinic & monoclinic \\
\hline Space group & $\mathrm{P}-1$ & $\mathrm{P} 2{ }_{1} / \mathrm{c}$ & $\mathrm{P} 22_{1} / \mathrm{n}$ \\
\hline $\mathrm{a} / \AA ̊$ & $7.6983(15)$ & $15.6201(9)$ & $11.308(2)$ \\
\hline $\mathrm{b} / \mathrm{A}$ & $11.726(2)$ & $12.1700(6)$ & $16.960(3)$ \\
\hline$c / \AA ̊$ & $11.813(2)$ & $17.5668(9)$ & $14.939(3)$ \\
\hline Alpha ${ }^{\circ}$ & $84.30(3)$ & 90 & 90 \\
\hline Beta/ ${ }^{\circ}$ & $80.53(3)$ & $115.995(7)$ & $102.13(3)$ \\
\hline Gamma/º & $78.47(3)$ & 90 & 90 \\
\hline Volume/Å ${ }^{3}$ & $1028.1(4)$ & $3001.5(3)$ & 2801.1(9) \\
\hline Z & 1 & 2 & 2 \\
\hline Dcalcd $/\left(\mathrm{g} \mathrm{cm}^{-3}\right)$ & 1.148 & 1.338 & 1.357 \\
\hline$\mu / \mathrm{mm}^{-1}$ & 0.068 & 0.782 & 0.831 \\
\hline$F(000)$ & 380.0 & 1268.0 & 1196.0 \\
\hline Crystal size $/ \mathrm{mm}^{3}$ & $0.211 \times 0.107 \times 0.049$ & $0.224 \times 0.079 \times 0.043$ & $0.125 \times 0.098 \times 0.033$ \\
\hline$\theta$ range $/^{\circ}$ & $3.504-54.892$ & $4.226-55$ & $3.68-54.938$ \\
\hline \multirow[t]{3}{*}{ Limiting indices } & $-9 \leq h \leq 9$ & $-20 \leq \mathrm{h} \leq 20$ & $-14 \leq \mathrm{h} \leq 14$ \\
\hline & $-15 \leq k \leq 15$ & $-15 \leq k \leq 15$ & $-22 \leq k \leq 21$ \\
\hline & $-15 \leq \mathrm{I} \leq 15$ & $-22 \leq 1 \leq 22$ & $-19 \leq 1 \leq 19$ \\
\hline No. of rflns collected & 14754 & 41623 & 38491 \\
\hline No. unique rflns & 4664 & 6887 & 6428 \\
\hline $\mathrm{R}$ (int) & 0.0600 & 0.0987 & 0.0875 \\
\hline No. of params & 268 & 408 & 332 \\
\hline Completeness to $\theta$ & 1.264 & 0.999 & 1.000 \\
\hline Goodness of fit on $F^{2}$ & 0.993 & 1.024 & 1.372 \\
\hline \multirow[t]{2}{*}{ Final $R$ indices $[I \geq 2 \sigma(I)]$} & $\mathrm{R}_{1}=0.1107$ & $\mathrm{R}_{1}=0.0844$ & $\mathrm{R}_{1}=0.1034$ \\
\hline & $w R_{2}=0.1945$ & $w R 2=0.1888$ & $w R_{2}=0.1621$ \\
\hline \multirow[t]{2}{*}{$\mathrm{R}$ indices (all data) } & $\mathrm{R}_{1}=0.1357$ & $\mathrm{R}_{1}=0.1362$ & $\mathrm{R}_{1}=0.1171$ \\
\hline & $w R_{2}=0.2069$ & $w R_{2}=0.2157$ & $w R_{2}=0.1674$ \\
\hline Largest diff. peak and hole/(e $\left.\AA^{-3}\right)$ & $0.19 /-0.21$ & $0.98 /-0.49$ & $0.46 /-0.33$ \\
\hline
\end{tabular}




\section{Conflicts of interest}

The authors declare no competing financial interest.

\section{Acknowledgements}

This work was supported by the National Natural Science Foundation of China (51473170 and 21871275). GAS thanks the Chinese Academy of Sciences for a President's International Fellowship for Visiting Scientists.

\section{Notes and references}

1 (a) G. J. P. Britovsek, V. C. Gibson, B. S. Kimberley, P. J. Maddox, S. J. McTavish, G. A. Solan, A. J. P. White, D. J. Williams, Chem. Commun., 1998, 849; (b) B. L. Small, M Brookhart, A. M. A. Bennett, J. Am. Chem. Soc., 1998, 120 4049.

2 (a) V. C. Gibson., C. Redshaw, G. A. Solan, Chem. Rev. 2007 107, 1745; (b) V. C. Gibson, G. A. Solan, Top. Organomet. Chem. 2009, 26, 107; (c) V. C. Gibson, G. A. Solan, in Catalysis without Precious Metals; Ed. Bullock, R. M.; Wiley-VCH: Weinheim, 2010, 111; (d) T. Xiao, W. Zhang, J. Lai, W.-H. Sun C. R. Chim. 2011, 14, 851; (e) J. Ma, C. Feng, S. Wang, K. Zhao, W.-H. Sun, C. Redshaw, G. A. Solan, Inorg. Chem. Front. 2014, 1, 14; (f) Z. Flisak, W.-H. Sun, ACS Catal. 2015, 5, 4713; (g) Z. Ma, W. Yang, Sun, W.-H. Chin. J. Chem. 2017, 35, 531; (h) Z. Wang, G. A. Solan, W. Zhang, W.-H, Sun. Coord. Chem. Rev. 2018, 363, 92.

3 (a) M. Delferro, T. J. Marks, Chem. Rev., 2011, 111, 2450; (b) H. Suo, G. A. Solan, Y. Ma, and W.-H. Sun, Coord. Chem. Rev., 2018, 372, 101.

4 C. Bianchini, G. Giambastiani, I. G. Rios, A. Meli, W. Oberhauser, L. Sorace, and A. Toti, Organometallics, 2007, 26, 5066 .

5 (a) S. Zhang, W.-H. Sun, X. Kuang, I. Vystorop, J. Yi, J. Organomet. Chem., 2007, 692, 5307; (b) S. Zhang, I. Vystorop, Z. Tang, and W.-H. Sun, Organometallics, 2007, 26, 2456; (c) W.-H. Sun, Q. Xing, J. Yu, E. Novikova, W. Zhao, X Tang, T. Liang, and C. Redshaw, Organometallics, 2013, 32 2309.

6 A. P. Armitage, Y. D. M. Champouret, H. Grigoli, J. D. A. Pelletier, K. Singh, and G. A. Solan, Eur. J. Inorg. Chem. 2008, 4597.

7 (a) J. Liu, Y. Li, J. Liu, and Z. Li, Macromolecules, 2005, 38 2559; (b) L. Wang, J. Sun, Inorg. Chim. Acta, 2008, 361, 1843.

8 (a) P. Barbaro, C. Bianchini, G. Giambastiani, I. G. Rios, A Meli, W. Oberhauser, A. M. Segarra, L. Sorace, and A. Toti, Organometallics, 2007, 26, 4639; (b) Q. Khamker, Y. D. M. Champouret, K. Singh and G. A. Solan, Dalton Trans., 2009, 8935.

9 D. Takeuchi, S. Takano, Y. Takeuchi, and K. Osakada, Organometallics, 2014, 33, 5316.

10 (a) Q. Xing, T. Zhao, Y. Qiao, L. Wang, C. Redshaw, and W.-H Sun, RSC Adv., 2013, 3, 26184; (b) Q. Xing, T. Zhao, S. Du, W. Yang, T. Liang, C. Redshaw, and W.-H. Sun, Organometallics, 2014, 33, 1382.

11 (a) Q. Chen, W. Zhang, G. A. Solan, T. Liang, W.-H. Sun, Dalton Trans., 2018, 47, 6124; (b) Q. Chen, W. Zhang, G. A Solan, R. Zhang, L. Guo, X. Hao, and W.-H. Sun, Organometallics, 2018, 37, 4002.
12 P. Buchwalter, J. Rose, P. Braunstein, Chem. Rev., 2015, 115 28.

13 (a) C. Bianchini, G. Mantovani, A. Meli, F. Migliacci, F. Zanobini, F. Laschi, A. Sommazzi, Eur. J. Inorg. Chem., 2003, 1620; (b) J. Yu, W. Huang, L. Wang, C. Redshaw, W.-H. Sun, Dalton Trans., 2011, 40, 10209.

14 (a) Y. Chen, R. Chen, C. Qian, X. Dong, and J. Sun, Organometallics, 2003, 22, 4312; (b) Z. Long, B. Wu, P. Yang, G. Li, Y. Liu, X.-J. Yang, J. Organomet. Chem., 2009, 694, 3793; (c) Y. D. M. Champouret, R. K. Chaggar, I. Dadhiwala, J. Fawcett, G. A. Solan, Tetrahedron, 2006, 62, 79; (d) Y.D.M. Champouret, J.-D. Maréchal, I. Dadhiwala, J. Fawcett, D. Palmer, G. A. Solan, Dalton Trans., 2006, 2350; (e) G. A. Griffith, M. J. Al-Khatib, K. Patel, K. Singh, G. A. Solan, Dalton Trans., 2009, 185; (f) Y.D.M. Champouret, J.-D. Maréchal, R.K. Chaggar, J. Fawcett, K. Singh, F. Maseras, G. A. Solan, New. J. Chem., 2007, 31, 75.

15 G. J. P. Britovsek, M. Bruce, V. C. Gibson, B. S. Kimberley, P. J. Maddox, S. Mastroianni, S. J. McTavish, C. Redshaw, G. A. Solan, S. Strömberg, A. J. P. White, D. J. Williams, J. Am. Chem. Soc., 1999, 121, 8728.

16 (a) F. Huang, W. Zhang, E. Yue, T. Liang, X. Hu, W.-H. Sun, Dalton Trans., 2016, 45, 657; (b) Z. Wang, G. A. Solan, Q. Mahmood, Q. Liu, Y. Ma, X. Hao, and W.-H. Sun, Organometallics, 2018, 37, 380; (c) Z. Wang, Y. Ma, J. Guo, Q. Liu, G. A. Solan, T. Liang and W.-H. Sun, Dalton Trans., 2019, 48, 2582; (d) Y. Huang, R. Zhang, T. Liang, X. Hu, G. A. Solan, and W.-H. Sun, Organometallics, 2019, 38, 1143.

17 (a) A. S. Abu-Surrah, K. Lappalainen, U. Piironen, P. Lehmus, T. Repo, M. Leskela, J. Organomet. Chem. 2002, 648, 55; (b) E. Yue, Y. Zeng, W. Zhang, Y. Sun, X. Cao, W.-H. Sun, Sci. China Chem. 2016, 59, 1291.

18 T. Xiao, J. Lai, S. Zhang, X. Hao, W.-H. Sun, Catal. Sci. Technol., 2011, 1, 462.

19 (a) G. J. P. Britovsek, S. Mastroianni, G. A. Solan, S. P. D. Baugh, C. Redshaw, V. C. Gibson, A. J. P. White, D. J. Williams, M. R. J. Elsegood, Chem. Eur. J., 2000, 6, 2221; (b) Y. Chen, C. Qian, and J. Sun, Organometallics, 2003, 22, 1231.

20 (a) D.P. Gates, S.A. Svejda, E. Oñate, C.M. Killian, L.K. Johnson, P.S. White, M. Brookhart, Macromolecules, 2000, 33, 2320; (b) H. Suo, I. I. Oleynik, C. Bariashir, I. V. Oleynik, Z. Wang, G. A. Solan, Y. Ma, T. Liang and W.-H. Sun, Polymer, 2018, 149, 45

21 T. Mao, P. Hao, G. Kehr, X. Hao, G. Erker, W.-H. Sun, Organometallics, 2011, 30, 4847.

22 (a) F. He, W. Zhao, X. Cao, T. Liang, C. Redshaw, W.-H. Sun, J. Organomet. Chem., 2012, 713, 209; (b) S. Du, W. Zhang, E. Yue, F. Huang, T. Liang, and W.-H. Sun, Eur. J. Inorg. Chem. 2016, 1748; (c) Q. Mahmood, E. Yue, J. Guo, W. Zhang, Y. Ma, X. Hao, W.-H. Sun, Polymer 2018, 159, 124; (d) C. Bariashira, Z. Wang, H. Suo, M. Zada, G. A. Solan, Y. Ma, T. Liang, W.-H. Sun, Eur. Polym. J., 2019, 110, 240.

23 G. B. Galland, R. Quijada, R. Rojas, G. Bazan, Z. J. A. Komon, Macromolecules, 2002, 35, 339.

24 (a) G. M. Sheldrick, Acta Crystallogr., Sect A: Found. Adv., 2015, 71, 3-8; (b) G. M. Sheldrick, Acta Crystallogr., Sect C: Struct. Chem., 2015, 71, 3.

25 L. Spek, Acta Crystallogr., Sect. D: Biol. Crystallogr., 2009, 65 148. 